\title{
The Impact of Operating Leases and Purchase Obligations on Credit Market Prices
}

\author{
Sandro C. Andrade Elaine Henry Dhananjay Nanda
}

Draft: March 2014.*

\begin{abstract}
We document that credit spreads are positively related to two types of executory contracts: noncancellable operating leases and unconditional purchase obligations. However, while leases and purchase obligations receive the same treatment by the Bankruptcy Code and current financial reporting rules, the credit spread impact per unit of leverage from purchase obligations is substantially less than that from leases. We conjecture that the effect of executory contracts on credit spreads depends on how essential the underlying assets or services are for the functioning of a bankrupt firm as a going concern. Essential contracts are likely to be unconditionally assumed by bankruptcy trustees, thus representing potentially higher post-default losses for holders of unsecured debt. Our findings potentially inform accounting standards that propose recognizing firms' operating lease obligations in financial statements while continuing to require solely footnoted disclosure of purchase obligations.
\end{abstract}

Keywords: Operating Leases, Purchase Obligations, Credit Spreads, Accounting Standards.

*Andrade and Nanda are from the University of Miami. Henry is from Fordham University. Please address correspondence to sca@miami.edu, ehenry6@fordham.edu, or d.nanda@miami.edu. We appreciate comments on an earlier version of this paper from workshop participants at University of Miami, and from Robert Bloomfield, Vidhi Chhaochharia, Andrew Leone and Peter Wysocki. We also thank David Dahan and Robyn King for research assistance and the Markit Group for CDS data. 


\section{Introduction}

We examine how firms' credit spreads in the Credit Default Swap (CDS) market are associated with two types of executory contracts, noncancellable operating leases and unconditional purchase obligations. ${ }^{1}$ We hypothesize that both types of contracts increase credit spreads on unsecured debt because they potentially represent senior, though off-balance sheet, obligations. That is, in case of bankruptcy a firm's off-balance sheet monetary commitments to counterparties in operating leases and purchase obligations potentially trump its commitments to unsecured debt holders. Our null hypothesis is that the credit spread impact of the two types of executory contracts is identical, given that both types of contracts (i) give rise to obligations that are effectively secured by related assets (operating leases) or by goods and services (purchase obligations) ${ }^{2}$, (ii) typically exclude provisions found in debt contracts under which a default would accelerate repayment or involuntary bankruptcy, (iii) receive similar treatment under the Bankruptcy Code, (iv) require similar disclosures under current financial reporting rules, and (v) are measured identically in our analysis. ${ }^{3}$

Our paper speaks to the question raised by Barth (2006, p.122): Should equal and offsetting rights and obligations from executory contracts be recognized in the balance sheet? This question is subject to debate among standard setters and users and producers of accounting information. This debate is consequential because the amounts of future cashflows committed under executory contracts such as purchase obligations and operating leases is substantial.

Our panel regressions of CDS spreads on leverage measures reveal that credit spreads are indeed positively associated with both leases and purchase obligations. However, we find that the effect of operating leases on spreads is substantially larger than the effect of purchase obligations. On average, with the mean CDS spread of 60 basis points as the baseline, a 10-percentage point increase in leverage due to an increase in the present value of operating

\footnotetext{
${ }^{1}$ An executory contract is one under which one or more parties has not yet completely fulfilled its obligations.

${ }^{2}$ A lessor's assets under lease are secured because the lessor retains title to the asset. A supplier's assets associated with a customer's purchase obligations are secured because the goods or services are still owned and controlled by the supplier (delivery has not occurred).

${ }^{3}$ Other research also shows that operating leases affect credit risk assessments (e.g., Kraft 2011, Batta et al. 2011, Altamuro et al. 2011, Lim et al. 2006). Ours however is the only paper documenting the effect of purchase obligations on credit spreads, and comparing the price effects of purchase obligations and operating leases, two types of executory contracts.
} 
leases raises spreads by 18 basis points. This impact is identical to that of a corresponding increase in balance sheet debt. In contrast, a 10-percentage point increase in leverage due to an increase in the present value of purchase obligations raises spreads by only 6 basis points.

We conjecture that the impact of leases and purchase obligations on credit spreads depends on the degree to which, on average, these executory contracts are perceived by credit market participants to be critical - i.e. essential - for the functioning of a bankrupt firm as a going concern. An obligation's essentiality matters because of the Bankruptcy Code's specific treatment of leases and purchase obligations. Depending on the circumstances, leases and purchase obligations can be effectively senior or effectively junior to unsecured debt. Section 365 of the Code, titled Executory contracts and unexpired leases, grants the debtor's estate the option to assume or to reject any lease or purchase obligation (Fried, 1996). The business judgment standard is used to evaluate whether a contract is assumed or rejected by the estate, and little consideration is given to the effect the decision has on the counterparty (Andrew, 1988, 1991). ${ }^{4}$ Thus, in Chapter 11 reorganization, if the bankruptcy estate deems that a contract is "essential" to the post-bankruptcy performance of the firm, it is more likely to assume the contract.

Assumed leases or purchase obligations are effectively senior to unsecured debt because (i) any default that may have already occurred in the assumed contract must be "cured", (ii) the original terms of the contract must be performed in full, and (iii) the debtor's estate (as opposed to the debtor itself) becomes bound to the contract. ${ }^{5}$ In essence, the original obligations of assumed contracts become liabilities of the debtor's estate. ${ }^{6}$ On the other hand, rejected leases or purchase obligations are effectively junior to existing unsecured debt because the injured party has less bargaining power than unsecured debt holders since (i)

\footnotetext{
${ }^{4}$ Under the "automatic stay" provided by the bankruptcy law, the non-debtor party to an executory contract must continue to perform during the bankruptcy proceeding while the assumption/rejection decision is made (Russell,2011.)

${ }^{5}$ Legal literature explaining that assumed executory contracts are considered senior to unsecured creditors includes, for example, Andrew (1988, 1991), Ayer (2003, 2004a,b), Fried (1996), and Maizel (2002).

6 " [Understanding] that the estate and the debtor are distinct legal entities - is crucial to understanding executory contracts doctrine. One important consequence of the distinction between the debtor and the estate is that the debtor's creditors, like the beneficiaries of an ordinary trust, are not in any direct sense creditors of the bankruptcy estate. They merely have a right, ultimately, to a distributive share of the estate, although that right is referred to as a 'claim.' The estate will, however, have its own creditors, for expenses incurred in the process of administration. Their claims, called 'administrative' claims, have priority over the claims of the debtor's unsecured creditors to distributive shares of the estate" (Andrew 1998, 852).
} 
they must sue for damages yet to be established, (ii) such damages are typically not easily verifiable in court, and (iii) litigation costs are typically high. ${ }^{7}$

The perceived essentiality of the underlying asset or goods and services reflects the likelihood that the corresponding lease or purchase obligation would be assumed or rejected by the debtor's estate, and therefore whether it would be effectively senior or effectively junior to unsecured debt in bankruptcy. Estate trustees are likely to assume an essential individual lease or purchase obligation even if its terms become individually onerous or unfavorable to the debtor because rejection would effectively shut down the business as a going concern. In other words, an essential executory contract (lease or purchase obligation) is likely to be unconditionally assumed by a debtors' estate. ${ }^{8}$ By affecting the debtor estate's decision to assume or reject, an obligation's essentiality affects the loss given default for unsecured debt holders. A higher essentiality implies a higher perceived likelihood of assumption regardless of contractual terms, thus higher perceived likelihood of seniority vis-à-vis unsecured debt, and therefore a higher expected loss given default for unsecured creditors. Therefore, ex ante, greater essentiality implies a higher credit spread, all else equal. The higher price impact of leases relative to purchase obligations that we find is consistent with leased assets being perceived, on average, as more likely to be deemed essential for the functioning of a bankrupt firm as a going concern, than are purchase obligations.

To further motivate our conjecture, we examine several recent bankruptcy filings by publicly traded US firms and their estate's assumption/rejection decisions regarding the debtor's existing executory contracts. Appendix A details each case. Our analysis of these filings suggests that the essentiality of an obligation seems to be the predominant reason determining whether an executory contract is assumed or rejected by a debtor's estate. Leases and purchase obligations that are deemed critical to the debtor's operations are assumed and

\footnotetext{
${ }^{7}$ If the estate does not assume an obligation, the debtor is not liable for performance on the executory contract and the creditor's claims for damages, after established in court, are treated as other unsecured claims (Andrew,1988).

${ }^{8}$ As Hahn (2011, page 730) notes: "Executory contracts may be extremely important to an insolvent company. Often the continuation of certain contracts will be the basis for the entire business operations of the debtor. ... As a practical matter, the continuation of the contract is critical because the costs and time entailed in negotiating and entering into an alternative contract might be significant. In these circumstances, entering into an alternative contract is an impracticable solution for the debtor, in view of its penurious situation. A debtor which becomes insolvent lacks two things: time and liquid funds. Any action required to keep its business alive which consumes these two resources, is doomed to failure."
} 
those that are not are rejected. For example, Reddy Ice Holdings, Inc., in their bankruptcy filing, filed a motion to assume a master lease for equipment used in its ice manufacturing lines and stated in their motion (italics added):

"The Debtors wish to assume the Master Equipment Lease Agreement because the Leased Equipment is essential to the Debtors' efforts to successfully restructure. The Leased Equipment, which is utilized in more than eighty (80) third party locations as well as several Debtor-operated facilities, significantly reduces the manufacturing, distribution and delivery costs associated with the Debtors' products and is integral to the Debtors' operations."

Our bankruptcy case analyses also suggest that operating leases are more often assumed than are purchase obligations. For instance, following their bankruptcy filing, Kodak's and Citadel Broadcasting Corporation's purchase obligations declined by more than their corresponding operating leases. Kodak's purchase obligations declined 57\% ( $\$ 717$ million to $\$ 310$ million) while its operating leases declined by only 17\% (\$292 million to $\$ 241$ million); Citadel Broadcasting Corporation's purchase obligations decreased 19\% (\$334 million to $\$ 271$ million) while its operating leases decreased by only 9\% (\$131 million to $\$ 119$ million). Similarly, in bankruptcy Bally Total Fitness assumed 330 leases while rejecting 70, whereas it assumed only 10 while rejecting 540 purchase contracts. In the bankruptcy filings that we examined, debtors-in-possession appear more likely to affirmatively assume (and provide details about) lease contracts than about other executory contracts. According to US Bankruptcy Code, any executory contract not affirmatively assumed by a debtor's estate is deemed to be rejected and is not the debtor estate's liability (Andrew, 1988). Thus, the relative paucity of information pertaining to the affirmative assumption/rejection of purchase obligations is perhaps additionally suggestive of debtor estates more frequently rejecting such executory contracts.

Further empirical tests support our conjecture that credit market's perceptions regarding the essentiality of executory contracts for the functioning of a going concern influence their impact on the cost of unsecured debt capital. We obtain individual 10-K disclosures about 
the nature of firms' purchase obligations, and manually classify our sample firms depending on how essential the underlying goods and services are for the functioning of a bankrupt firm as a going concern. We code each firm's purchase obligations as belonging to one of three groups; high, moderate and low essentiality. For example, Hershey's obligations to purchase raw materials (cocoa, corn syrup, milk, sugar etc.) from specific suppliers at pre-determined prices are classified as having low essentially, and thus likely to be rejected by its debtor's estate if their terms are unfavorable for the going-concern, since these raw materials are commodities traded in large spot markets served by many different suppliers. In contrast, Verizon Communications' obligations to purchase network services, equipment, and software are classified as having high essentiality, and thus are likely to be assumed by bankruptcy trustees and paid in full even if their terms become individually onerous or unfavorable to the bankrupt debtor. Verizon's debtors-in-possession are likely to assume these contracts regardless of their terms because these are fundamental intermediate inputs for their business, and are likely to be provided by specialized suppliers, and thus less likely to be replaceable. Consistent with our conjecture, our results show that the credit market price effect of a purchase obligation depends on its assessed degree of essentiality. We find that the credit spread effect per unit of leverage associated with purchase obligations is statistically equal to the price effect of leases when the degree of essentiality of purchase obligations is high, and statistically equal to zero when the degree of essentiality is low. The credit spread effect for the group with moderate essentiality (or missing information) is nonzero and similar to the full sample average price effect of purchase obligations.

We consider alternative explanations for our empirical results. First, distressed firms are potentially more likely to lease assets and are less likely to have purchase obligations since their vendors may be unwilling to enter into purchase contracts. Consequently, high CDS spreads due to distress may lead to greater leasing and lower purchase obligations; i.e. reverse causation. However, we find that the differential effect on CDS spreads of operating leases and purchase obligations is more pronounced in the sub-sample of investment grade firms (i.e. non-distressed) relative to speculative grade firms (i.e. distressed). Thus, reverse causality is an unlikely explanation for our findings. Second, leases and purchase obligations potentially 
have differential information content about a firm's future cash flows. We examine this explanation by incorporating controls for information content in our research design as the disclosure requirements of the two types of obligations are similar. Our tests show that the differential information content of purchase obligations and operating leases does not explain their differential price impact. Third, the existence of leases and purchase obligations may affect a company's risk profile. However, the risk impact would explain our findings only if the risk impact of leases and purchase obligations differs. We incorporate controls for risk in our research design, and given the similarity of the impact on the probability of bankruptcy and the similarity of the economic function of leases and purchase obligations (both of which hedge expected asset requirements), we are able to reject this explanation.

The contribution of this paper is twofold. First, ours is the first and so far only paper documenting the valuation of disclosed data on purchase obligations for debt investors. We put forth and validate an economic conjecture explaining why the price effect of purchase obligations is on average smaller than that of operating leases, a similarly computed and disclosed corporate obligation. By showing that an accounting disclosure is useful for debt investors, this paper contributes to the growing finance and accounting literature on credit risk pricing.

Second, we believe our paper belongs to the subset of valuation papers that can potentially inform standard setting, as it speaks to the debate of whether rights and obligations from executory contracts should be recognized in the balance sheet. There are conflicting views. Currently, debt and capital leases are recognized as liabilities, whereas operating leases and purchase obligations are disclosed in financial statement footnotes, and, since 2004, additionally disclosed in the MD\&A section of financial filings. The Financial Accounting Standards Board's (FASB 2013) newly-proposed leasing standard will require firms to recognize substantially all obligations and related assets for leases longer than one year on the balance sheet, whereas purchase obligations will remain off-balance sheet. Several organizations have criticized both the initial and revised leasing exposure drafts (FASB 2013b). Criticism ranges from the leasing industry plea for the status quo to the CFA Institute recommendation that both purchase obligations and leases should be fully recognized. To wit, in its 
invited comments to the FASB and IASB's initial exposure draft, Ernst and Young (2010) notes:

"The Boards should articulate a clear conceptual basis for the differentiation between leases and other non-lease executory contracts. Without a clear articulation of the Boards' rationale for affording such drastically different accounting to leases, we struggle to understand the principles that led the Boards to their decisions."

In contrast to the current FASB proposal, and seemingly supporting the notion that leases and purchase obligations should be treated equally with respect to recognition versus disclosure, the Bankruptcy Code treats both types of corporate obligations similarly. As previously discussed, Section 365 of the Code grants the debtor's estate the option to assume or to reject any executory contract or unexpired lease of the debtor. The law provides the bankruptcy trustee with the same option to accept or to walk away from leases or purchase obligations; however, the trustee's decision will relate to the essentiality to the firm of the underlying leased assets and the underlying goods and services under purchase obligations. If the underlying leased assets tend to be more critical in the functioning of the bankrupt firm as a going concern than the underlying purchase-obligation for goods and services, the leases would tend to be more likely assumed than the purchase obligations. In turn, the greater likelihood of assumption would increase the overall credit spread effect on the firm, as discussed before. Our empirical analysis shows that, per unit of leverage, the credit spread effect of leases is equal in magnitude to that of balance sheet debt, while the credit spread effect of purchase obligations, though non-zero, is substantially smaller. Similar to the probability continuum concept governing recognition of contingencies, it could be argued that the differential credit pricing of leases and purchase obligations reflects their different economic characteristics (likelihood of assumption versus rejection in bankruptcy as we posit) which in turn could justify differential accounting treatment. 


\section{Hypotheses and Empirical Specifications}

In this section we enumerate our hypotheses and explain how our research design leads to implications about coefficients on the variables in our credit spread regressions. We also elaborate on a few aspects of our research design that are particularly relevant in interpreting results from the credit risk pricing model that we use for our empirical tests.

\subsection{Initial Hypotheses Tests}

Our empirical examination relies on regressing 5-year Credit Default Swap (CDS) spreads on determinants of credit spreads, including measures of noncancellable operating leases and unconditional purchase obligations. As noted by Barth, Beaver, and Landsman (2001, 91), a primary research design consideration for value relevance research is the selection of the valuation model that is used in the tests. Thus, using a structural valuation model rooted in theory is an important aspect of our research design. In our empirical tests, we adopt the well established credit-risk pricing model of Davydenko and Strebulaev (2007), which derives from Merton's (1974) seminal debt-pricing model and subsequent theoretical extensions.

Davydenko and Strebulaev (2007) classify the structural determinants of credit spreads into two categories: strategic variables and non-strategic variables. The non-strategic determinants of credit spreads include the three variables in Merton (1974): leverage, asset volatility, and risk-free rates. As we explain in detail in Section 3, we decompose leverage into three components: balance sheet debt (B/S Debt), noncancellable operating leases (Op. Leases), and unconditional purchase obligations (Purchase Obligations). These three components add up to total firm leverage, and we focus on their relative effect on credit spreads. Because we use time fixed effects in our regressions, we do not include the risk-free rate as an independent variable. Our time fixed effects represent a different intercept for each quarter and capture time variation in the risk-free rate as well as in other determinants of aggregate credit spreads. The fourth non-strategic variable is the log of a firm's book value of assets. A firm's book value of assets proxies for the quality of its information environment, and is motivated by Duffie and Lando (2001) who show that firms with less timely or precise 
information have higher credit spreads even when lenders are risk-neutral and symmetrically informed.

The strategic determinants of credit spreads in Davydenko and Strebulaev (2007) reflect extensions to Merton's (1974) model allowing for violations of the absolute priority rule (APR) in the event of bankruptcy (e.g., Anderson and Sundaresan, 1996; Mella-Barral and Perraudin, 1997; Fan and Sundaresan, 2001). That is, whereas shareholders are wiped out in case a firm goes bankrupt in the Merton model, in practice they still retain a considerable fraction of the value of the bankrupt firm (Eberhart, Moore, and Roenfeld, 1990). The the-

oretical extensions allowing for APR violations predict that credit spreads are higher when renegotiation between shareholders and bondholders is less costly, and when shareholders possess greater bargaining power in bankruptcy proceedings. Davydenko and Strebulaev (2007) proxy for these effects using a number of variables. Non-fixed assets proxy for the costs of liquidation, short-term debt ratio and number of institutional equity investors proxy for renegotiation frictions, and institutional ownership and CEO shareholding proxy for shareholders' relative bargaining power. Davydenko and Strebulaev (2007) find that these variables have significant coefficients in regressions of credit spreads, and therefore are important, theoretically motivated control variables for empirical analyses of credit spreads.

We estimate the following baseline regression model (omitting fixed effects and time and firm subscripts):

$$
\begin{aligned}
\log (\text { Spread })= & \beta_{0}+\beta_{1} B / S \text { Debt }+\beta_{2} \text { Op. Leases }+\beta_{3} \text { Purchase Obligations } \\
& +\beta_{4} \text { Asset Volatility }+\beta_{5} \text { LogAssets }+\Omega \text { Strategic }+\varepsilon
\end{aligned}
$$

Our initial hypotheses can be summarized as follows:

\author{
Hypothesis 1: Credit spreads are positively associated with noncancellable op- \\ erating leases: $\beta_{2}>0$.
}

Hypothesis 2: Credit spreads are positively associated with unconditional purchase obligations: $\beta_{3}>0$. 
Hypothesis 3: The price effects of balance sheet debt, noncancellable operating leases, and unconditional purchase obligations on credit spreads are equal: $\beta_{1}=\beta_{2}=\beta_{3}$.

\subsection{Essentiality Conjecture}

To test our conjecture regarding the relation between credit spreads and the essentiality of obligations, we examine individual firms' 10-K descriptions of their purchase obligations. We create a dummy variable, Essential, that equals 1 when the goods and services described in purchase obligations appear to be vital and irreplaceable for the functioning of the firm as a going concern. When Essential is equal to 1, credit market participants should expect that bankruptcy trustees will assume the purchase obligations contracts even if these are otherwise individually onerous (financially unfavorable) for the bankrupt firm, because rejection would lead to immediate suspension of operations and eventual liquidation. Analogously, we create a dummy variable Non-Essential that equals 1 when purchase-obligation goods and services appear non-vital or replaceable. We describe our coding of the Essential and Non-Essential dummy variables in Section 3.

In our tests, we interact the dummy variables Essential and Non-Essential with Purchase Obligations and estimate the following regression model:

$$
\begin{aligned}
\log (\text { Spread })= & \beta_{0}+\beta_{1} B / S \text { Debt }+\beta_{2} \text { Op. Leases }+\beta_{3} \text { Purchase Obligations }+ \\
& \theta_{E} \text { Purchase Obligations } \times \text { Essential }+\theta_{N E} \text { Purchase Obligations } \times \text { Non-Essential } \\
& +\beta_{4} \text { Asset Volatility }+\beta_{5} \text { LogAssets }+\Omega \text { Strategic }+\varepsilon
\end{aligned}
$$

Our final hypothesis is:

Hypothesis 4: The price effect of purchase obligations is higher when purchase obligations appear to be essential and lower when purchase obligations appear non-essential: $\theta_{E}>0, \theta_{N E}<0$. 


\subsection{Conceptual clarifications}

Before proceeding to the description of our data and results, we clarify certain conceptual aspects of our research design. Because our focus is on credit risk, we use a credit spread valuation model adapted from Davydenko and Strebulaev (2007) rather than a balance sheet equity valuation model often used in the value relevance literature. These clarifications are important because they help rule out alternative explanations for our findings, and cover four areas: hedging or risk-incentive effects, information effects, net versus gross value of contracts, and the recognition of onerous executory contracts.

Hedging or risk-incentive effects. The pre-determination of future rents or prices (and quantities) implicit in operating leases and purchase obligations could potentially reduce credit spreads by reducing risk. On the other hand, Triantis (1993) argues that the specific treatment of executory contracts by the Bankruptcy Code creates incentives for debtors with executory contracts to take on more risk, as it grants the debtor an option to walk away from onerous or unfavorable contracts. This would imply that operating leases and purchase obligations could increase credit spreads by increasing risk. Our framework accounts for

any potential risk-reducing or risk-increasing effects associated with executory contracts. As in Merton's (1974) framework, these potential benefits translate into lower or higher asset volatility. Consequently, we use asset volatility as a control variable in our empirical specifications.

Information effects. Our framework accounts for the possibility that firms enter into long term operating leases and purchase obligations when they expect high demand for their products. In our framework, any potential information content of either operating leases or purchase obligations is reflected in higher current stock prices (and thus lower leverage), leading, all else equal, to lower credit spreads. Note that our explanatory variables $B / S$ Debt, Op. Leases, and Purchase Obligations are constructed as leverage components. As we explain in detail in Section 3, the current market value of equity is used in constructing all three variables. 
Net vs. gross value of contracts. In economic terms, every operating lease and purchase obligation represents both an asset and a liability. For example, to a first approximation, if a purchase obligation of goods and services is made at actuarially fair prices, the net value of the purchase obligation is close to zero at inception. However, over time the net value may deviate from zero. If we were pursuing a value relevance study for equity valuation using the balance sheet model, we would likely benefit from using the net rather than (or in addition to) the gross value, as Venkatachalam (1996) does for bank derivative positions. However, since we are using a debt valuation model (more precisely, credit spread valuation model) we focus on the future cash flows committed under balance sheet debt, operating leases, or purchase obligations, not on net values. The netting out is implicit in our use of stock market equity values when defining the leverage components B/S Debt, Op. Leases, and Purchase Obligations.

Recognition of onerous contracts. If a purchase obligation pertains to goods and services for which there is a verifiable market price, and if this market price has subsequently declined below the commitment price (subject to materiality thresholds), the amount of the unrealized loss must be recognized along with a corresponding on-balance sheet obligation (FASB ASC 330-10-35-17). There is a similar, albeit less general, requirement to recognize unrealized losses on operating leases that are "without economic benefit to the entity" (FASB ASC 420-10-25-1). Note, however, that i) partially recognized purchase obligations or leases are not listed as off-balance sheet contractual obligations, and as such are not included in our Purchase Obligations or Op. Leases leverage measures; ii) partially recognized purchase obligations or leases do not appear on the balance sheet as Debt (short-term or long-term), and thus are excluded from our $B / S$ Debt leverage measure. Therefore, early recognition of onerous executory contracts (which, incidentally, is rare) does not bias our inference regarding the relative price effects of $B / S$ Debt, Op. Leases, and Purchase Obligations. 


\section{Data and Measures}

Our dependent variable is the (log) spread of a firm's 5-year credit default swap (CDS). A credit default swap is essentially a form of insurance against default by a particular firm, known as the reference entity. The buyer of default protection makes a periodic payment to the seller of default protection, and if the reference entity defaults on its obligations, the buyer receives compensation. Specifically, the CDS gives a buyer the right to sell to the protection seller - at par - a bond issued by the reference entity if a credit event occurs. CDS spreads are tied to bond spreads by an arbitrage relation (Duffie, 1999): the CDS spread for a firm is equal to the difference between the yield on a floating-rate bond of the same maturity issued by the firm and the risk-free rate. Therefore, similar to bond yield spreads, CDS spreads can be approximated by the probability of default times the expected loss given default. CDS spreads are particularly useful in empirical studies of credit risk pricing because they are supposedly less affected by non-default components (for example, liquidity and taxes) than bond yields spreads (see Longstaff, Mithal, and Neis (2005)).

Markit Group is our source for CDS spread data. Markit collects quotes from a large sample of CDS dealers and aggregates them into a composite number after filtering out outliers and stale observations. Quotes are for CDS contracts using senior unsecured debt of North American obligors as reference obligations. Following prior literature (e.g., Jorion and Zhang

2009; Kim, Kraft, and Ryan 2013), we focus on 5-year U.S. dollar denominated contracts with the modified restructuring clause. We collect quarter-end CDS spread observations from March 2004 to March 2006. Note that we use quarterly data on CDS spreads even though information on purchase obligations and operating leases is released annually: the reason is that we have higher frequency data on other determinants of spreads such as balance sheet debt, total assets, and asset volatility. Therefore, using quarterly data allows us to sharpen our inference about the coefficients on purchase obligations and operating leases. 
COMPUSTAT is our primary source of data on noncancellable operating lease obligations. ${ }^{9}$ Our purchase obligation data is manually collected from the MD\&A section of Form 10-K filings with the SEC. Beginning with fiscal years ending on or after December 15, 2003, SEC disclosure rule FR-67 - "Disclosure in Management's Discussion and Analysis about Off-Balance Sheet Arrangements and Aggregate Contractual Obligations" mandated disclosure in the MD\&A of contractual obligations including purchase obligations (SEC 2003). Disclosure of contractual obligations must be presented using a specific tabular format that shows payments due by period, with amounts due after five years presented as a lump sum.

We merge Markit's CDS data with CRSP/COMPUSTAT, eliminating firms with SIC code between 6000 and 6999 or SIC code between 4900 and 4949. Firms with these SIC codes are considered financial firms and utilities respectively, for which data on noncancellable operating lease obligations is not available on COMPUSTAT. We use annual COMPUSTAT data for noncancellable lease obligations (items MRC1 through MRC5, and MRCTA) and quarterly data for the other accounting variables. To ensure that the accounting data we use is available to market participants at the time of the CDS spread observation, we assume a three-month lag between fiscal-quarter dates (i.e., COMPUSTAT datadates) and CDS spread dates. Our Markit/CRSP/COMPUSTAT data has 3,096 firm-quarter observations and 388 firms. This data is merged with purchase obligations data obtained from firms' $10-\mathrm{K}$ filings. The combined dataset has 2,864 firm-quarter observations and 376 firms.

Following Davydenko and Strebulaev (2007), our estimates of asset volatility rely on data from Moody's KMV. We obtain time series of asset values from Moody's KMV, and compute historical asset return volatility over the previous six months, after removing outliers by trimming daily asset returns at the $5 \%$ level in each tail for each firm. Outliers typically correspond to corporate events such as changes in capital structure (SEOs, stock repurchases, mergers and acquisitions etc.). We annualize asset volatilities by multiplying by the square root of 252. After merging the Markit/CRSP/COMPUSTAT/10-K data with Moody's KMV asset volatility estimates, our sample has 2,846 firm-quarter observations and 372 firms.

\footnotetext{
${ }^{9}$ Bratten et. al. (2012), documents that creditors and equity investors treat the reliability of as-if recognized operating lease obligations and recognized capital lease obligations identically. They find that the present values of disclosed operating lease obligations do not differ statistically in their equity and bond price impacts from capital lease obligations.
} 
Finally, we merge our Markit/CRSP/COMPUSTAT/10-K/Moody's KMV data with the Thompson Financial Ownership database. The Financial Ownership data are used to calculate the fraction of equity owned by institutional investors, and the normalized number of institutional equity investors. We are able to match all of our observations; therefore our final sample still has 2,846 firm-quarter observations and 372 firms. ${ }^{10}$

We discount future operating lease and purchase obligations to present value in order to make them comparable to balance sheet debt. We use Standard \& Poor's CreditStats method to allocate obligations over years 6 and beyond (Standard \& Poor's 2002). Standard \& Poor's methodology assumes a constant obligation for years 6 and beyond. For example, for leases, the number of years after year 5 is the closest integer to MRCTA divided by MRCT5. The constant obligation on years 6 and beyond is equal to MRCTA divided by the number of years after year 5 . Obligations are discounted to present value using the risk free rate, defined as the 5-year swap rate minus 10 basis points (see Hull et al., 2004). The 5-year swap rate is obtained from Datastream. We label the present value of noncancellable lease obligations $P V$ Leases and the present value of purchase obligations PV Purchase Obligations.

We define three main leverage-related variables: B/S Debt, Op. Leases, and Purchase Obligations. These variables are subcomponents of firm leverage. B/S Debt is the component of total leverage due to balance sheet debt obligations (including short- and long-term debt):

$$
B / S \text { Debt }=\frac{\text { Debt }}{\text { Mkt. Value of Equity }+ \text { Debt }+P V \text { Leases }+P V \text { Purchase Obligations }} .
$$

Note that both $P V$ Leases and $P V$ Purchase Obligations appear in the denominator of $B / S$ Debt. This is because $B / S$ Debt is the component of total leverage attributable to balance sheet debt, in the spirit of Merton's (1974) debt pricing model. Op. Leases is the component of total leverage due to noncancellable operating leases:

$$
\text { Op. Leases }=\frac{P V \text { Leases }}{M k t . \text { Value of Equity }+ \text { Debt }+P V \text { Leases }+P V \text { Purchase Obligations }},
$$

\footnotetext{
${ }^{10}$ In robustness tests, described in section 4 , we replace our measure of asset volatility with equity volatility and our results remain robust.
} 
and Purchase Obligations is the component of total leverage due to unconditional purchase obligations:

Purchase Obligations $=\frac{P V \text { Purchase Obligations }}{\text { Mkt. Value of Equity }+ \text { Debt }+P V \text { Leases }+P V \text { Purchase Obligations }}$.

Note that total firm leverage is given by: B/S Debt + Op. Leases + Purchase Obligations. Table 1 summarizes our variables and data sources, and Table 2 provides summary statistics.

\section{Tables 1 and 2}

Table 2, Panel A shows that the average log spread for firms in our sample is 3.71, corresponding to a spread of 41 basis points. The average spread in the sample is 60 basis points. The large difference between mean spread and mean log spread suggests considerable skewness in spreads. In later analyses, we use Median regressions to rule out the possibility that our results are affected by the remaining skewness in log spreads. There is substantial variation in spreads: the width of a two-standard deviation interval around the mean log spread is $\exp (3.71+2 \times 0.77)-\exp (3.71-2 \times 0.77)=181$ basis points. Similarly, the table shows there is also considerable dispersion in our explanatory variables.

Note that the average leverage ratio including only on-balance sheet debt is equal to 0.190, while the average total leverage ratio including operating leases is equal to $0.190+0.038=$ 0.227 , and the average total leverage ratio including operating leases and purchase obligations is equal to $0.190+0.038+0.060=0.287$. The typical firm in our sample is fairly large: the median amount of total assets is equal to $\$ 8.6$ billion, compared to $\$ 3.5$ billion for non-financial, non-utility publicly traded firms on COMPUSTAT in the 2004-2006 period.

Table 2, Panel B shows that the component of leverage due to operating leases is weakly correlated with volatility (-0.07) and with the on-balance sheet component of leverage (0.01). The other correlations between explanatory variables in the same specification are not excessively high, indicating that our OLS regression results are not affected by multi-collinearity. The correlation between Op. Leases and log credit spreads is 0.24 , and the correlation 
between Purchase Obligations and log credit spreads is 0.07 .

Essentiality. We examine individual firms' 10-K descriptions of their purchase obligations to create the dummy variables Essential and Non-Essential. Essential equals 1 when the goods and services described in purchase obligations appear to be vital and irreplaceable for the functioning of the firm as a going concern. Non-Essential is equal to 1 when the goods and services appear non-vital or replaceable. If Essential equals 1, then investors should expect the purchase obligation to be unconditionally assumed by bankruptcy trustees. If Non-Essential equals 1, then investors should expect rejection, unless the purchase obligation is favorable for the bankrupt firm. If both Essential and Non-Essential are equal to zero, then either the purchase obligation rates moderate in terms of essentiality or information is missing. Essential is equal to 1 for $20 \%$ of our sample while Non-essential is equal to 1 for $23 \%$ of our sample.

Our coding of the Essential and Non-Essential dummy variables is premised on a few principles. First, purchase obligations related to commoditized raw materials are likely to be Non-Essential, because these raw materials can be purchased from a multiple suppliers in large spot markets. Second, purchase obligations related to capital expenditures are likely to be Non-Essential because it is unlikely that a bankrupt firm invests in expanded physical capital in order to keep functioning as a going concern. Third, purchase obligations related to specialized intermediate inputs are likely to be Essential. Fourth, purchase obligations for retail stores are likely to be inventory (unless otherwise mentioned) and thus likely to be Essential. Fifth, when multiple purchase-obligation goods and services are mentioned without the corresponding individual dollar values, it is assumed that the earlier mentioned obligations are larger than later mentioned obligations. Appendix B provides examples of our coding of firms' purchase obligations' essentiality. ${ }^{11}$

\footnotetext{
${ }^{11}$ The classifications were based on the authors' judgments. The authors individually read and coded each firm's disclosures about purchase contracts. Subsequently, any disagreement was discussed and resolved. The dataset is available upon request.
} 


\section{Results}

In this Section we report results of empirically testing our hypotheses. In subsection 1, we describe the results of estimating our baseline specification, and performing the initial hypotheses tests. Results of robustness checks are discussed in subsection 2. Tests of our essentiality conjecture are presented in subsection 3.

\subsection{Initial Hypotheses Tests}

Table 3 displays results of regressions testing whether, on average in our 2003-2005 sample period, CDS spreads are associated with noncancellable operating lease obligations and unconditional purchase obligations. In all regressions we follow Petersen's (2009) recommendation and use standard errors that are robust to heteroskedasticity and clustered at the firm level.

\section{Table 3}

Column (1) reports results of regressing log CDS spreads on non-strategic variables, ignoring noncancellable operating leases and purchase obligations. For consistency, and for comparison with the extant credit pricing literature that ignores executory contracts, in Column (1) the variable $B / S$ Debt omits $P V$ Leases and $P V$ Purchase Obligations from the denominator. Our results are similar to those of the extant literature: credit spreads are positively associated with leverage $(B / S$ Debt) and volatility (Asset Volatility), and negatively associated with with size (Log of Assets).

In Column (2), we augment the baseline structural model by introducing both noncancellable operating leases and unconditional purchase obligations as additional explanatory variables. ${ }^{12}$ We find that the coefficients on both Op. Leases and Purchase Obligations are statistically significant at the $1 \%$ level. We conclude that the data support our hypotheses (H1) and (H2) that credit spreads are positively associated with obligations from noncan-

\footnotetext{
${ }^{12}$ In untabulated regressions we add these variables separately (with or without including PV Purchase Obligations in the definition of Op. Leases and with or without including PV Leases in the definition of Purchase Obligations) and find that their coefficients are statistically significant at the $1 \%$ level.
} 
cellable operating leases unconditional purchase obligations. Note that the coefficient on $O p$. Leases is 3.46 , similar in magnitude to the 3.93 coefficient on $B / S$ Debt, whereas the coefficient on Purchase Obligations is 1.04, substantially smaller than that of $B / S$ Debt. Tests reported on Panel B of Table 3 show that we cannot reject the hypothesis that the coefficients on $O p$. Leases and $B / S$ Debt are equal, whereas we can reject the hypothesis that the coefficient on Purchase Obligations is equal to the coefficient on Op. Leases.

Finally, Column (3) adds strategic variables from Davydenko and Strebulaev (2007). Results are similar to those of the extant literature: credit spreads are positively associated with leverage components, Asset Volatility, and Non-Fixed Assets; and negatively associated with Short-term Debt Ratio, Log of Assets, and Normalized No. of Institutional Shareholders. The adjusted R-square for Column (4) is 0.561, substantially higher than the R-squareds in Table IX of Davydenko and Strebulaev (2007), which are below 0.40 in all their specifications. Again, results indicate that credit spreads are positively related to Op. Leases and Purchase Obligations and that the relative effect of noncancellable operating lease obligations is greater than that of unconditional purchase obligations.

Results in Column (3) indicate that on average in our sample period, and with the mean spread of 60 basis points as a baseline, a 10 percentage point increase in leverage due to an increase in the present value of noncancellable operating lease obligations raises credit spreads by 18 basis points $(\exp (\ln (60)+2.68 \times 0.10)-60)$. The price effect of operating leases is similar in magnitude to the price effect of balance sheet debt: a 10 percentage points increase in leverage due to balance sheet debt raises credit spreads by 23 basis points $(\exp (\ln (60)+3.25 \times 0.10)-60)$. In contrast, a 10 percentage point increase in leverage due to an increase in the present value of unconditional purchase obligations raises credit spreads by 6 basis points $(\exp (\ln (60)+0.90 \times 0.10)-60)$. As shown in Panel B of Table 2, the difference between the coefficients on $O p$. Leases and Purchase Obligations is statistically significant.

In summary, Panel B of Table 2 presents results of formal tests of the equivalence of the price effect of $B / S$ Debt, Op. Leases, and Purchase Obligations. These tests reject our null hypothesis (H3) that the relative price effects of balance sheet debt, noncancellable operating lease obligations and unconditional purchase obligations are equal. 


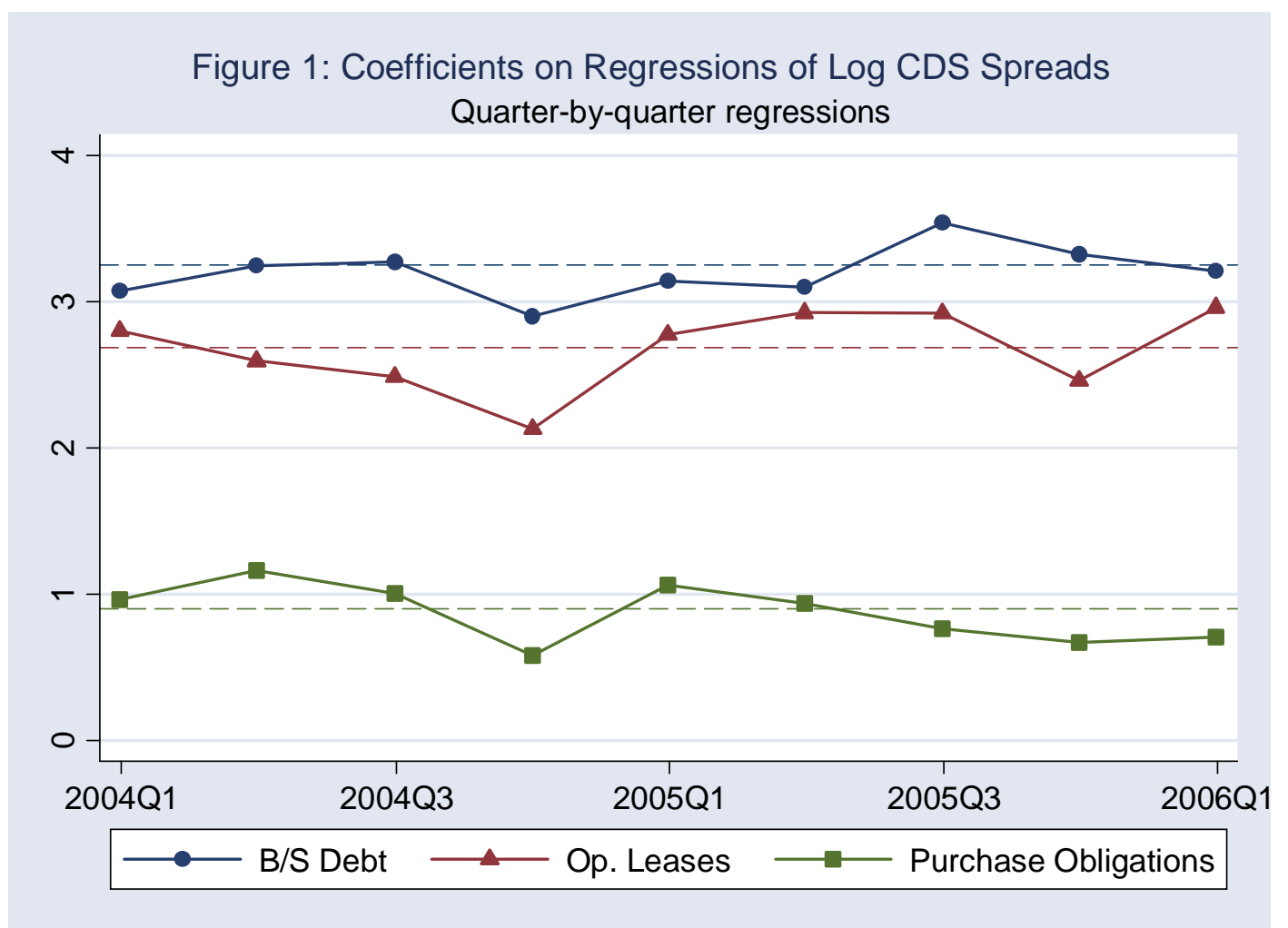

\subsection{Robustness checks}

In this section we describe results of several additional tests to attest to the robustness of our baseline results. First, we examine whether there is any apparent time variation in the relative price effects of balance sheet debt, operating leases, and purchase obligations. Next, we examine whether our results are sensitive to alternative samples, specifications, and statistical methods.

Figure 1 presents a graph of the coefficients on $B / S$ Debt, Op. Leases, and Purchase Obligations, which are derived from estimating the regression in Column (3) of Table 3 quarter by quarter, rather than for the entire 2004 to 2006 period. The horizontal dashed lines represent the coefficients obtained in the full sample regression in Column (3) of Table 3. Note that there is no discernible time trend in the overall relations among the coefficients. Therefore, the visual evidence in Figure 1 indicates that the relative price-effect of balance sheet debt, 
operating leases, and purchase obligations does not appear to vary over our sample period.

\section{Table 4}

Table 4 reports results of robustness regressions that verify whether our results are sensitive to alternative samples, specifications, and statistical methods. In Column (1) we repeat our regression in column (3) of Table 3 but use a balanced panel, that is, we only include firms in the sample that are present in all 9 quarter-ends (247 firms). The number of quarterly firm observations drops from 2,846 to 2,223 . We find that the Op. Leases and Purchase Obligations remain statistically significant at the 1\% level, thus Hypothesis 1 and 2 are robust to this sampling method. Tests of Hypothesis 3 (untabulated) also confirm results from the main analysis, that the relative price effect of noncancellable operating lease obligations is greater than that of unconditional purchase obligations.

In Columns (2) and (3) we repeat our regression separately for investment grade and speculative grade firms. ${ }^{13}$ First note that the coefficients on $O p$. Leases remain statistically significant at the $1 \%$ level in both subsamples and the coefficients on Purchase Obligations are statistically significant at the $1 \%$ and $5 \%$ level for the investment grade and speculative grade firms, respectively. Tests of Hypothesis 3 (untabulated) also confirm that the relative price effect of noncancellable operating lease obligations is greater than that of unconditional purchase obligations for investment grade firms only. For speculative grade firms, however, tests fail to reject the hypotheses of equivalent price effect of noncancellable operating lease obligations and unconditional purchase obligations. Note, however, that the coefficient on Op. Leases is still substantially larger than the coefficient on Purchase Obligations

There are two potential explanations for the smaller gap between the credit spread effect of leases and purchase obligations among speculative grade firms compared to investment grade ones. First, it is likely that speculative grade firms, being distressed, face greater difficulty in finding counterparties for purchase obligations because vendors are reluctant to

\footnotetext{
${ }^{13}$ Table 2 shows that, in the entire sample, the averages of Op. Leases and Purchase Obligations are respectively 0.038 and 0.060 . Among investment grade firms only (2305 observations), the averages are respectively 0.034 and 0.060. Among speculative grade firms only (541 observations), the averages are respectively 0.052 and 0.059 .
} 
write purchase contracts with a potentially bankrupt firm. As a result, it is likely that these firms do not enter into new purchase obligation contracts with providers of non-essential goods and services, and as result their purchase obligations are, on average, more essential. This is consistent with our manually coded classification of essentiality. Among speculative grade firms, the distribution of observations across high, moderate, and low essentiality is respectively $(24 \%, 55 \%, 21 \%)$, whereas among speculative grade firms the distribution is $(19 \%, 57 \%, 24 \%)$. Second, the failure to formally reject Hypothesis 3 is potentially due to reduced statistical power in the smaller speculative grade sample. Indeed, note further that the coefficients on other explanatory variables (e.g., Non-Fixed Assets and Short-term Debt Ratio) are also statistically insignificant in the speculative grade sample, while their economic magnitudes remain similar to the full sample case.

Note that results in columns (2) and (3) of Table 4 help us mitigate concerns that our baseline results are driven by reverse causality, i.e., the credit spread effect of purchase obligations is smaller than that of operating leases because distressed firms have difficulty in finding counterparties for purchase obligations. This reverse causality explanation is inconsistent with the larger gap between the credit spread effects of operating leases and purchase obligations among non-distressed, investment grade firms.

In column (4) of Table 4 we discount each firm's noncancellable operating lease obligations and unconditional purchase obligations at the firm's cost of debt (risk-free rate plus 5-year CDS spread) rather than at the risk-free rate and re-estimate our regression specification. In column (5) we replace asset volatility with equity volatility implied in the prices of 30-day at-the-money calls. Our main tests utilize annualized volatility of the firm's assets obtained from Moody's KMV, as a proxy for asset volatility; this specification addresses potential concerns related to using data from a commercial vendor. In column (6) we include the CEO Shareholding variable, an additional strategic variable identified by Davydenko and Strebulaev (2007). Since this variable is unavailable for our full sample the regression is estimated over a reduced sample size.

In column (7) of Table 4 we include two additional explanatory variables: current profitability, as measured by the ratio of earnings before interest and taxes (EBIT) to book value 
of assets, and interest coverage. ${ }^{14}$ Under Merton's (1974) framework, the information contained in both variables is subsumed by leverage, which depends on current stock prices. However, frictions in raising capital in credit markets potentially give rise to defaults due to a "shortage of cash", even when the equity market sees long-term value. We find that the coefficients on both profitability and interest coverage are negative as expected, however neither is statistically significant at the $5 \%$ level. Moreover, our conclusions regarding the relative magnitude of the leverage coefficients are unchanged. In Column (8) we include Industry-Effects (i.e., a different dummy variable for each industry) using the Fama-French 10-industry classification. Our results are robust to each of these modifications: the coefficient on operating lease obligations and purchase obligations are statistically significant, with the coefficient on operating leases being higher than the coefficient on purchase obligations. Further, tests of Hypothesis 3 (untabulated) for each of these specifications also confirm results from the main analysis that the relative price effect of noncancellable operating lease obligations is greater than that of unconditional purchase obligations.

We also explore an alternative empirical estimation method to ensure the robustness of our OLS estimates. In Column (9) of Table 4 we estimate the regression model using a Median regression procedure with the same sample and variables as used in Column (3) of Table 3. The reported standard errors are obtained by bootstrapping 10,000 times with clustering at the firm level. Finally, in Column (10) we use standard errors clustered by quarter and by firm separately. This in an important robustness check, as recent research by Gow, Ormazabal, and Taylor (2010) shows that numerous results in the credit spread valuation literature are not robust to double clustering. In both Column (9) and Column (10) our conclusions remain the same: noncancellable operating lease obligations and unconditional purchase obligations are both statistically significant determinants of credit spreads, but the price effect of operating leases is greater than that of unconditional purchase obligations.

\subsection{Essentiality conjecture}

We conjecture that the differential effect of operating leases and purchase obligations on

\footnotetext{
${ }^{14}$ Interest coverage is defined as interest expense divided by EBIT, winsorized at $1 \%$ in both tails.
} 
credit spreads stems from the differential (average) essentiality of the assets and goods and services underlying the two types of obligations. To further examine this conjecture, we manually classify 10-K disclosed purchase obligations based on how essential the underlying goods and services are for the functioning of the bankrupt firm as a going concern. The dummy variable Essential is 1 when the degree of essentiality is high and the dummy variable Non-Essential is 1 when the degree is low. Both variables are zero if the degree of essentiality is moderate, or when there is no information about the nature of purchase obligations. We interact Essential and Non-Essential with Purchase Obligations and report regression results in Table 5.

\section{Table 5}

Table 5 shows that the coefficient on the Purchase Obligations $\times$ Essential is positive and statistically significant in both Columns (1) and (2). The coefficient on Purchase Obligations $\times$ Non-Essential is negative in both columns, statistically significant in Column (1) and insignificant in Column (2) $(t$-stat=-1.25). The sum of the Column (2) coefficients on Purchase Obligations and Purchase Obligations $\times$ Essential equals $1.89+0.61=2.50$, similar in magnitude to the coefficient on $O p$. Leases which is 2.58. Panel B shows that the difference is statistically equal to zero, that is, the price effect of purchase obligations is statistically equal to the price impact of operating leases when Essential is equal to 1. The sum of the Column (2) coefficients of Purchase Obligations and Purchase Obligations $\times$ Non-Essential equals $-0.56+0.61=0.05$, very close to zero. Panel B shows that the price effect of purchase obligations is statistically equal to zero when Non-Essential is equal to 1 . These results support our conjecture that the effect of executory contracts on credit spreads depend on credit markets' beliefs about the likelihood that these contracts are assumed by a bankruptcy estate.

Our Essential and Non-Essential interaction effects not only provide evidence supporting our conjecture that the differential price effect of leases and purchase obligations stems from differences in the average degree of essentiality, but further mitigates concerns that our results are driven by plausible alternative explanations such as risk-change effects or information effects of different types of obligations. As we previously discussed, our framework includes 
Asset Volatility, which serves as a control for the potential risk-changing effects associated with executory contracts; thus, to the extent that Asset Volatility is a good control, our main results are not explained by potential differences on the risk-reducing (hedging) or risk-increasing effects purchase obligations vis-a-vis operating leases. Nonetheless, even if Asset Volatility does not adequately control for risk, our essentiality interactions indicate that risk-changing effects do not provide a satisfactory explanation of our results. This is because there is no a priori reason to believe that purchase obligations associated with essential goods and services would be less risk-reducing than purchase obligations associated with non-essential goods and services.

Similarly, we argue earlier that our framework accounts for any information that purchase obligations or leases may have about future business prospects, as such information would reduce leverage today through its impact on current stock prices. However, information effects are potentially still an alternative explanation for a differential price impact if (i) leases, as opposed to purchase obligations, do not provide good information, and (ii) CDS markets incorporate information that is not yet impounded in equity prices. Nonetheless, our essentiality interactions indicate that information effects do not provide a satisfactory explanation for our results since there is no a priori reason to believe that purchase obligations associated with essential goods and services signal "less relevant" information about firm prospects than purchase obligations associated with non-essential goods and services. Therefore, it is unlikely that our results are driven by any potential "good" signal that purchase obligations (but not leases) reveal to the CDS market.

\section{Conclusion}

We examine how two types of executory contracts, noncancellable operating leases and unconditional purchase obligations, affect CDS spreads. We find that credit spreads are positively associated with both leases and purchase obligations. However, per unit of leverage, the credit spread effect of operating leases is substantially larger than that of purchase obligations, even though both types of corporate obligations receive similar treatment in the 
Bankruptcy Code and current financial reporting rules, and are measured by us in a similar way.

We conjecture that the larger credit price effect of operating leases vis-à-vis purchase obligations stems ultimately from the credit market's perception that, on average, leased assets are more essential for the functioning of a bankrupt firm than are purchase obligations of goods and services. If so, compared to purchase obligations, leases are more likely to be assumed rather than rejected by bankruptcy trustees, regardless of the original terms of the contracts. Since assumed and rejected executory contracts are, respectively, effectively senior and effectively junior to unsecured debt, leases are, as compared to purchase obligations, associated with larger losses given default for holders of unsecured debt.

We provide further evidence consistent with our conjecture. We examine individual firms' 10-K descriptions of their purchase obligations, and classify firms into three groups depending on the degree to which their underlying goods and services are essential for the functioning of a bankrupt firm as a going concern. We find that the credit spread effect per unit of purchase obligation leverage is economically equivalent to the effect of leases when the degree of essentiality of purchase obligations is high, and equal to zero when their degree of essentiality is low.

Our results potentially inform the current debate on whether or to what extent a firm's executory contracts should be recognized on its balance sheet, a question also posed by Barth $(2006,122)$. In particular, our results are pertinent to the proposed leasing standard that would require firms to recognize substantially all leasing obligations and related assets on the balance sheet for leases over one year, whereas purchase obligations would remain off-balance sheet. Nevertheless, standard setters are ultimately responsible for weighing the complex social welfare trade-offs associated with standard setting (Holthausen and Watts, 2001; Barth et al., 2012); our results merely provide additional evidence that is potentially relevant for the process. 


\section{Appendix A. Disposition of Executory Contracts in Bankruptcy}

This appendix presents 5 examples of the treatment of unexpired leases and purchase obligations in US bankruptcy cases. We present this information as case examples for two reasons. First, to the best of our knowledge, available bankruptcy databases do not have directly relevant information on rejected and assumed executory contracts. The American Bankruptcy Institute's "Bankruptcy Research Database" does not include rejected/assumed executory contracts among the list of data items in its Protocol. ${ }^{15}$ Research based on the "Business Bankruptcy Project" focuses on aspects not directly pertinent to our topic such as numbers and types of creditors (Warren and Westbrook 2004) and numbers of bankruptcy trials over time (Warren 2004). Only summary information is presented in Fried (1996, footnote 21) who examined a small sample of Chapter 11 cases, including eight completed cases in which the debtor had multiple executory contracts. In three of the eight cases, all of the executory contracts had been rejected, and in the other five cases, at least one contract had been assumed.

The second reason we present this information as case examples is that the information concerning rejection or assumption of executory contracts displays significant variation. For example, some debtors' court documents enumerate each executory contract that is rejected and each that is assumed (e.g. Bally Fitness, Case 4). Others provide only an incomplete list. ${ }^{16}$ For example, Black Gaming LLC, has a single word in its Schedule of Rejected Executory Contracts and Unexpired Leases: "None." Black Gaming's bankruptcy plan does not include a schedule of assumed executory contracts. (Because of inadequate relevant information, we do not include Black Gaming among our examples.)

Where a plan document does exist, we obtain information from bankruptcy filings. ${ }^{17}$ In some cases, particularly those that are currently in Chapter 11 (e.g. Kodak, case 5), we obtain

\footnotetext{
${ }^{15}$ See http://lopucki.law.ucla.edu/index.htm.

16 "There remains the question of contracts that are neither assumed nor rejected before the confirmation of the plan. Do we assume that they are implicitly rejected? Or implicitly assumed? There is no compelling answer to this question. Prudent counsel sidesteps it by language in the Code, as, for example 'all executory contracts not explicitly assumed are deemed rejected."' (Ayer 2004a.)

17 "The ultimate objective of a chapter 11 case is confirmation of a plan. The plan is the document that sets forth the terms of the reorganization. It is the 'contract' that rewrites the relationship between the debtor and its creditors and shareholders (and often other parties)" (Ayer et al. 2004c).
} 
information about assumption and rejection primarily from "first day motions."

Debtor's counsel typically seeks a number of orders in the first days of the case in an effort to minimize the disruption caused by chapter 11. Certain of these "first-day orders," as they are called, are designed to override statutory prohibitions of the Bankruptcy Code. For example, the Code generally prohibits a debtor from paying any pre-petition debts, so a debtor may file a motion seeking permission to pay pre-petition employee wages or pre-petition claims of critical trade vendors. Other first-day orders are sought to take advantage of powers uniquely given to a debtor in bankruptcy. For example, a motion to reject executory contracts may be filed as a first-day motion. (Ayer et al. 2003).

Motions requesting authority to reject or assume unexpired leases and executory contracts typically include the following as bases:

- $\quad$ The Bankruptcy Code provides that a debtor in possession may "reject any executory contract or unexpired lease of the debtor" subject to court approval (11 U.S.C. $\S$ 365(a).)

- The provision for rejecting an executory contract "allows a trustee to relieve the bankruptcy estate of burdensome agreements which have not been completely performed." (Kodak: Debtors' Motion for an Order Authorizing Rejection of Certain Unexpired Nonresidential Real Property Leases citing case law.)

- The Debtors' rejection of an executory contract or unexpired lease is governed by the business judgment standard, which "requires a court to approve a debtor's business decision unless that decision is the product of bad faith, whim or caprice." (Kodak: Debtors' Motion for an Order Authorizing Rejection of Certain Unexpired Nonresidential Real Property Leases citing case law.)

In addition to the bankruptcy code provisions and case law precedents, Debtors' motions include specific information supporting the claim that the proposed course of action is in the best interest of the estate and creditors. 


\section{Case 1: Reddy Ice Holdings, Inc.}

Reddy Ice, a manufacturer and distributor of packaged ice, filed for Chapter 11 bankruptcy on April 12, 2012. The company's filing was structured as a prepackaged bankruptcy (Palank, 2012), i.e. one in which the reorganization plan has been approved by the majority of creditors prior to the actual filing. Because a prepackaged bankruptcy enables a debtor to exit Chapter 11 relatively quickly, it is considered a useful approach for businesses that are particularly sensitive to public image, such as retailers (Ayer et al. 2005).

Leases. ${ }^{18}$ In the week following the initial filing, Reddy filed a motion to assume a master lease for equipment used in its ice manufacturing lines (e.g., pelletizing and shrink-wrapping equipment) and for self-contained machines at third-party locations that produce, package, and store ice. Among the bases for relief, the motion stated: "The Debtors wish to assume the Master Equipment Lease Agreement because the Leased Equipment is essential to the Debtors' efforts to successfully restructure. The Leased Equipment, which is utilized in more than eighty (80) third party locations as well as several Debtor-operated facilities, significantly reduces the manufacturing, distribution and delivery costs associated with the Debtors' products and is integral to the Debtors' operations." Also following the initial filing, Reddy filed a motion to assume leases for trailers (i.e., vehicles used to deliver ice.) The motion pertained to existing trailers already being leased, trailers for which Reddy and the lessor had made a prepetition agreement for their manufacture and subsequent lease, and additional trailers which Reddy required for its seasonal needs (as 60\% to 70 percent of Reddy's profits result from seasonal demand.) In this motion, Reddy states that the trailer lessor company "constitutes a critical vendor."

Critical Vendors. ${ }^{19}$ Reddy's first day motion for authorization to pay prepetition claims of critical suppliers notes that it "[does] business with many of the Critical Vendors without the benefit of contracts and, therefore, these Critical Vendors generally are not obligated to do business with the Debtors or to honor particular trade terms in the future. As such,

\footnotetext{
${ }^{18}$ Retrieved from:

http://www.kccllc.net/documents/1232349/1232349120418000000000004.pdf http://www.kccllc.net/documents/1232349/1232349120427000000000015.pdf

${ }^{19}$ Retrieved from: http://www.kccllc.net/documents/1232349/1232349120412000000000020.pdf
} 
failure to pay the Critical Vendor Claims would likely result in a disruption or cancellation of deliveries of goods and services and thus, undermine the Debtors' operations." 20 The motion states in a footnote that Critical Vendors with which Reddy has a service or supply agreement would remain obligated to perform the agreement, but there would nevertheless be a need to "litigate with their Critical Vendors to compel them to perform under their contracts should they refuse to provide goods and services consistent to (sic) the terms of any contract with the Debtors."

Other Executory Contracts. ${ }^{21}$ Reddy's plan of reorganization contains only general language with regard to other executory contracts. As of May 11, 2012, the detailed schedules of assumed and rejected contracts had not yet been filed.

\section{Case 2: Borders Group, Inc.}

Borders Group Inc., founded in 1971, filed for bankruptcy on February 16, 2011. At the time of the filing, Borders was among the leading operator of book, music and movie superstores, and mall bookstores, operating 642 retail outlets. Borders Group Inc. ceased all operations on September 18, 2011 by closing the remaining 399 stores that day.

Non-residential Real Property Leases. ${ }^{22}$ At the filing date, all 642 stores possessed by the Debtors were nonresidential real property leases. In First Day Motions, the debtors filed a motion to reject four of these leases. Further, the properties had already been vacated, so the rejection of the unexpired lease would be retroactive to the date when the properties was vacated. The motion states: "Because the Debtors' no longer maintain operational retail stores at the Leased Premises, continued compliance with the terms of the Leases would be burdensome and would provide no corresponding benefit to the Debtors or the stakeholders in these chapter 11 cases." The motion goes on to state: "The Debtors have also reviewed

\footnotetext{
${ }^{20}$ Criteria used to identify critical vendors include: "(a) whether the vendor in question is a "sole-source" or "limited source" provider, (b) the costs and delay associated with identifying and qualifying a replacement, (c) whether the Debtors receive advantageous pricing or other terms from a Vendor such that replacing the Vendor postpetition would result in significantly higher costs to the Debtors, and (d) the overall impairment on the Debtors' operations that would result if the particular Critical Vendor ceased or delayed services or shipments."

${ }^{21}$ Retrieved from: http://www.kccllc.net/documents/1232349/1232349120412000000000024.pdf

${ }^{22}$ Debtors' omnibus motion filed in the United States Bankruptcy Court, Southern District of New York, February 16, 2011.
} 
the market value of the Leases and determined that marketing the Leases for assignment or sublease to a third party would not generate any significant value for the estates." The Debtors argue that the motion should be approved since the business judgment rule applies to the decision to reject leases. Rejection of the Leases would allow the Debtors to achieve cost savings of approximately $\$ 22.7$ million in rent and related obligations over the remaining terms of the contracts.

Executory Contracts - Service Agreements. The Debtors filed their first motion to reject executory contracts on May 19, 2011 with the rejection effective June 2, 2011, although the Debtors had filed a First Day Motion for extension to review executory contracts. As of the filing date, the Debtors estimated that they were party to 809 executory contracts, not including store leases. The Motion sought approval to reject 100 contracts that had been reviewed as of the filing date. These contracts included linen rental agreements, maintenance agreements, security agreements and other contracts for services that were no longer required following the closure of 225 stores. In the twelve months prior to the motion, the Debtors had paid $\$ 9.4$ million for services to counterparties to the rejected contracts. The Motion also sought authority to reject any or all of the remaining contracts that had not been reviewed as of May 19, 2011. The motion stated: "the Debtors respectfully submit that establishing streamlined procedures for rejecting any or all of the Remaining Contracts will save the estates the significant time and administrative expense of filing a motion for each Contract to be rejected." The motion was approved. On July 12, 2011, the Debtors rejected another 24 executory contracts related to software services and security agreements. On October 25, 2011, the Debtors rejected 12 additional contracts related to service agreements. On December 9, 2011, the Debtors filed a motion to assume 20 executory contracts. 


\section{Borders Group Significant Contractual Obligations from Form 10-K MD\&A Disclosures}

\begin{tabular}{lrr}
\hline (\$ millions) & December 31, 2011 & December 31, 2010 \\
\cline { 2 - 3 } Credit Agreement borrowings & $\$ 168.5$ & $\$ 232.3$ \\
Term Loan borrowings & 48.8 & 42.5 \\
Operating lease obligations & 263.5 & 291.2 \\
Capital lease obligations & 1.2 & 1.3 \\
Debt of consolidated VIEs & - & 0.2 \\
Letters of credit & 33.7 & 37 \\
& $\$ 515.7$ & $\$ 604.9$ \\
\hline
\end{tabular}

\section{Case 3: Citadel Broadcasting Corporation}

Citadel Broadcasting Corporation, a radio broadcasting company, filed for bankruptcy on December 20, 2009. Its plan of reorganization was confirmed on May 17, 2010.

Non-residential Real Property Leases. ${ }^{23}$ Citadel's first day motions sought to reject two building leases on property previously used for network sales operations and general office space but no longer occupied. Citadel's plan exhibits included one rejected tower/transmitter lease and one rejected equipment lease. Citadel's plan exhibit of assumed executory contracts and unexpired leases (149 pages long) included approximately 106 assumed equipment leases, 155 assumed real property leases, and 143 assumed tower/transmitter leases.

Other Executory Contracts. ${ }^{24}$ Citadel's first day motions sought to reject 11 executory contracts, including content agreements, tower agreements and employment agreements. Citadel's plan exhibits included 12 additional rejected executory contracts, including programming agreements and employment agreements. Citadel's plan of assumed executory contracts and unexpired leases included approximately 2,200 assumed executory contracts, such as employee services contracts, union agreements and programming contracts.

\footnotetext{
${ }^{23}$ Retrieved from: http://www.kccllc.net/documents/0917442/0917442091220000000000066.pdf

${ }^{24}$ Retrieved from: http://www.kccllc.net/documents/0917442/0917442100423000000000004.pdf
} 


\section{Citadel's Contractual Obligations from Form 10-K MD\&A Disclosures}

\begin{tabular}{lrr}
\hline (\$ millions) & December 31, 2010 & December 31,2009 \\
\cline { 2 - 3 } Debt and future interest & $\$ 1,088.0$ & $\$ 2,233.9$ \\
Operating leases & 119.3 & 131.1 \\
Other broadcast programming & 166.3 & 183.7 \\
Sports broadcasting and employment contracts & 105.1 & 151.0 \\
Other contractual obligations & 114.2 & 73.2 \\
Supplemental employee retirement plan (2) & 18.7 & \\
\cline { 2 - 3 } & $\$ 1,611.6$ & $\$ 2,772.9$ \\
\hline
\end{tabular}

\section{Case 4: Bally Total Fitness}

Bally Total Fitness, a fitness center operator with 349 centers and 3.1 million members as of September, 2008, filed for bankruptcy on December 3, 2008.

Non-residential Real Property Leases. ${ }^{25}$ On various dates during the six months after filing for Chapter 11, the Debtors rejected leases relating to approximately 70 locations because they were identified as "underperforming and burdensome to the estate." Six months after filing, the Debtors assumed approximately 330 unexpired leases, which "constituted the bulk of the Debtors' operating locations."

Critical Vendors. ${ }^{26}$ The first day motions included a motion to pay the prepetition claims of 10 critical vendors, including providers of waste management services, supplies such as nutritional supplements and beverages for retail sale, and TV service and atmospheric music at the Debtors' fitness clubs (the loss of which, it was argued, would "give Club Members the impression that the quality of the Debtors' clubs was declining and that the Debtors were spiraling towards liquidation rather than reorganization.") The motion specifically states that it should not be construed as a "request for authority to assume any executory contract or unexpired lease" under section 365 .

Other Executory Contracts. ${ }^{27}$ Exhibits attached to the plan of reorganization show about 10 executory contracts for services being assumed and cured compared to about 90 pages (list-

\footnotetext{
${ }^{25}$ Retrieved from: http://www.kccllc.net/documents/0814818/0814818090707000000000026.pdf

${ }^{26}$ Retrieved from: http://www.kccllc.net/documents/0814818/0814818081205000000000011.pdf

${ }^{27}$ Retrieved from: http://www.kccllc.net/documents/0814818/0814818090731000000000034.pdf
} 
ing about 6 items per page) of executory contracts being rejected. The executory contracts being assumed included inter alia credit card agreements with American Express, service agreements with ATT and T-Mobile, a music licensing agreement, a marketing agreement, and an energy contract. The executory contracts being rejected included service agreements (e.g., for cleaning, extermination, a human resources, advertising), marketing agreements, and other types of contracts (e.g., a Guaranteed Severance Agreement, a Key Employee Change of Control, Confidentiality, Non-Solicitation and Non-Compete Agreement).

\section{Case 5: Eastman Kodak Company}

Kodak, formerly a leading producer of cameras and film, was founded in 1880. The Company filed for bankruptcy on January 19, 2012.

Non-residential Real Property Leases. ${ }^{28}$ As of the filing date, the Debtors had approximately 34 nonresidential real property leases across 12 states. The First Day Motions included a motion to reject five of these leases. The leases are those "that are not integral to the Debtors' ongoing business operations and represent an unnecessary expense to the estates." For each of the properties, the motion states: "The Debtors have determined that they do not need the [Premises] in the operation of their businesses." Rejection of the Leases would save the Debtors up to a maximum of approximately $\$ 3.2$ million in annual rental and operating expenses (net of any sublease income).

Aircraft Leases. ${ }^{29}$ As of the filing date, the Debtor had two Aircraft Leases. The First Day Motions included a motion to reject both leases.

Critical Vendors. ${ }^{30}$ As of the filing date, the Debtors estimated that they had approximately 2,000 vendors with outstanding prepetition claims in the aggregate amount of approximately $\$ 332$ million. (Although the Debtors' accounts payable system was estimated to contain approximately 6,000 vendors, only about 2,000 had open balances at the time of filing.) The First Day Motion sought approval to pay the prepetition claims of certain

\footnotetext{
${ }^{28}$ Retrieved from: http://www.kccllc.net/documents/1210202/1210202120119000000000017.pdf.

${ }^{29}$ Retrieved from: http://www.kccllc.net/documents/1210202/1210202120119000000000013.pdf

${ }^{30}$ Retrieved from: http://www.kccllc.net/documents/1210202/1210202120118000000000028.pdf
} 


\section{Kodak's Contractual Obligations MD\&A Disclosures from 10-K}

\begin{tabular}{lrr}
\hline & December 31, 2011 & December 31, 2010 \\
\cline { 2 - 3 } Purchase Obligations* & $\$ 310$ million & $\$ 717$ million \\
Operating Lease Obligations & $\$ 241$ million & $\$ 292$ million \\
Long-term Debt & $\$ 1,618$ million & $\$ 1,363$ million \\
\hline
\end{tabular}

*“Purchase obligations include agreements related to raw materials, supplies, production and administrative

services, as well as marketing and advertising, that are enforceable and legally binding on the Company and that

specify all significant terms, including: fixed or minimum quantities to be purchased; fixed, minimum or variable

price provisions; and the approximate timing of the transaction. Purchase obligations exclude agreements that are

cancelable without penalty. The terms of these agreements cover the next one to eleven years."

\section{Critical Vendors up to an aggregate cap of $\$ 40$ million where such payment is necessary to} ensure supply on a postpetition basis. ${ }^{31}$

\footnotetext{
${ }^{31}$ Critical Vendors were defined as "suppliers and service providers that: (a) provide unique goods or services that are otherwise unavailable or (b) provide goods or services that the Debtors are unable to procure without incurring significant migration costs or compromising quality." Arguing for the importance of Critical Vendors the Motion stated: "Given the specialized type of goods and the complexity of services required to maintain the Debtors' operations, the Debtors firmly believe that certain Critical Vendors could not be replaced within a reasonable time or on terms as beneficial to the Debtors as those already in place. Moreover, if a Critical Vendor were to refuse to do business with the Debtors, the resulting disruption in supply of raw materials, components and finished goods would ripple through the Debtors' businesses, idling production of certain product lines and the ability to service existing products or, in some cases, entire production facilities, and damaging the Debtors' ability to create final products or to deliver goods to customers (and, therefore, maintain customer relationships and generate revenue), all to the detriment of the Debtors' estates and their creditors. Further, given that many product lines are managed globally with common vendors serving multiple regions, a disruption to the Debtors' operation could have a ripple effect on the Debtors' foreign affiliates." The Motion also refers to the "carefully-choreographed, highly-integrated stages of development, production and delivery realized through a synchronization of the numerous third-party suppliers, vendors and service providers within the Debtors' global supply chain network."
} 


\section{Appendix B}

\section{Purchase Obligation Essentiality}

\begin{tabular}{|c|c|c|}
\hline Firm & Description & Essentiality \\
\hline ALLTEL Corp. & $\begin{array}{l}\text { Purchase obligations represent amounts payable under non-cancelable contracts } \\
\text { and include commitments for wireless handset purchases, network facilities and } \\
\text { transport services, agreements for software licensing and long-term marketing } \\
\text { programs. }\end{array}$ & High \\
\hline Alcoa Inc. & Raw material and other purchase obligations & Low \\
\hline Baker Hughes Inc. & $\begin{array}{l}\text { Purchase obligations include agreements to purchase goods or services that are } \\
\text { enforceable and legally binding and that specify all significant terms, including: } \\
\text { fixed or minimum quantities to be purchased; fixed, minimum or variable price } \\
\text { provisions; and the approximate timing of the transaction. Purchase obligations } \\
\text { exclude agreements that are cancelable at anytime without penalty. }\end{array}$ & Moderate \\
\hline C R Bard Inc. & $\begin{array}{l}\text { The company's business creates a need to enter into commitments with suppliers. } \\
\text { In accordance with accounting principles generally accepted in the United States, } \\
\text { these purchase obligations are not reflected in the accompanying consolidated } \\
\text { balance sheets. These inventory purchase commitments do not exceed the } \\
\text { company's projected requirements over the related terms and are in the normal } \\
\text { course of business. }\end{array}$ & Moderate \\
\hline Chevron Corp. & $\begin{array}{l}\text { Long-Term Unconditional Purchase Obligations and Commitments, Throughput } \\
\text { Agreements and Take-or-Pay Agreements The company and its subsidiaries have } \\
\text { certain other contingent liabilities relating to long-term unconditional purchase } \\
\text { obligations and commitments, throughput agreements, and take-or-pay } \\
\text { agreements, some of which relate to supplier's financing arrangements. The } \\
\text { agreements typically provide goods and services, such as pipeline and storage } \\
\text { capacity, utilities, and petroleum products, to be used or sold in the ordinary course } \\
\text { of the company's business. The aggregate approximate amounts of required } \\
\text { payments under these various commitments are } 2006-\$ 2.2 \text { billion; } 2007- \\
\$ 1.9 \text { billion; } 2008 \text { - } \$ 1.8 \text { billion; } 2009-\$ 1.8 \text { billion; } 2010-\$ 0.5 \text { billion; } 2011 \text { and } \\
\text { after - } \$ 3.8 \text { billion. Total payments under the agreements were approximately } \\
\$ 2.1 \text { billion in } 2005 \text {, } \$ 1.6 \text { billion in } 2004 \text {, and } \$ 1.4 \text { billion in } 2003 \text {. The most } \\
\text { significant take-or-pay agreement calls for the company to purchase approximately } \\
55,000 \text { barrels per day of refined products from an equity affiliate refiner in } \\
\text { Thailand. This purchase agreement is in conjunction with the financing of a } \\
\text { refinery owned by the affiliate and expires in } 2009 \text {. The future estimated } \\
\text { commitments under this contract are: } 2006 \text { - } \$ 1.3 \text { billion; } 2007-\$ 1.3 \text { billion; } \\
2008 \text { - } \$ 1.3 \text { billion; and } 2009 \text { - } \$ 1.3 \text { billion. In } 2005 \text {, under the terms of an } \\
\text { agreement entered in } 2004 \text {, the company exercised its option to acquire additional } \\
\text { regasification capacity at the Sabine Pass Liquefied Natural Gas Terminal. } \\
\text { Payments of } \$ 2.5 \text { billion over the } 20 \text {-year period are expected to commence in } \\
2009 \text {. }\end{array}$ & High \\
\hline $\begin{array}{l}\text { Brinker International } \\
\text { Inc. }\end{array}$ & $\begin{array}{l}\text { A "purchase obligation" is defined as an agreement to purchase goods or services } \\
\text { that is enforceable and legally binding on the Company and that specifies all } \\
\text { significant terms, including: fixed or minimum quantities to be purchased; fixed, } \\
\text { minimum or variable price provisions; and the approximate timing of the } \\
\text { transaction. The Company's purchase obligations primarily consist of long-term } \\
\text { obligations for the purchase of telecommunication services, certain non-alcoholic } \\
\text { beverages and baked goods and exclude agreements that are cancelable without } \\
\text { significant penalty. }\end{array}$ & Moderate \\
\hline
\end{tabular}


Chiron Corp.

Electronic Data
Systems Corp.

GA Pac Corp.

Gillette Co.
Technology services agreement(5)(5) Effective August 1, 2003, Chiron and IBM Corporation amended and restated the previous ten-year information technology services agreement which was effective on July 1, 1998. Under this revised agreement, IBM agreed to provide us with a full range of information services until March 31, 2010. We can now terminate this agreement, subject to certain termination charges. At December 31, 2005, minimum future payments to IBM are expected to be approximately $\$ 39.6$ million. Payments to IBM are subject to adjustment depending upon the levels of services and infrastructure equipment provided by IBM, as well as inflation. Purchase orders(6) We had noncancelable purchase orders for ongoing operations of \$74.2 million at December 31, 2005.

Purchase obligations include material agreements to purchase goods or services, principally software and telecommunications services, that are enforceable and legally binding on EDS and that specify all significant terms, including: fixed or minimum quantities to be purchased; fixed, minimum or variable price provisions; and the approximate timing of the transaction. Purchase obligations exclude agreements that are cancelable without penalty. Purchase obligations also exclude our obligation to repurchase minority interests in joint ventures, including our obligation to repurchase Towers Perrin's minority interest in ExcellerateHRO.

The majority of our purchase obligations are take-or-pay contracts made in the ordinary course of business related to raw material purchases and utilities contracts. Other significant items included in the above table reflect purchase obligations related to advertising agreements and legally binding commitments for capital projects. Purchase orders made in the ordinary course of business are excluded from the above table. Any amounts for which we are liable under purchase orders are reflected in our consolidated balance sheet as accounts payable and accrued liabilities.

The amounts indicated in this line primarily reflect future contractual payments under various take-or-pay arrangements or firm commitments entered into as part of the normal course of business. Commitments made under take-or-pay obligations represent future purchases in line with expected usage to obtain favorable pricing. While the amounts listed represent contractual obligations, we do not believe it is likely that the full contractual amount would be paid if the underlying contracts were canceled prior to maturity. In such cases, we generally are able to negotiate new contracts or cancellation penalties, resulting in a reduced payment. The amounts do not include obligations related to other contractual purchase obligations that are not take-or-pay arrangements or firm commitments. Such contractual purchase obligations are primarily purchase orders at fair value that are part of normal operations and are reflected in historical operating cash flow trends. We do not believe such purchase obligations will adversely affect our liquidity position.
Low

High

Low

Moderate 


\section{References}

[1] Aboody, D., Barth, M.E., Kasznik, R., 1999. Revaluations of fixed assets and future firm performance: Evidence from the UK. Journal of Accounting and Economics 26, 149-178.

[2] Aboody, D., M. E. Barth, and R. Kasznik, 2004. Firms' voluntary recognition of stock-based compensation expense. Journal of Accounting Research 42 (2): 123-150.

[3] Aboody, D., M. E. Barth, and R. Kasznik, 2004b. SFAS N. 123 Stock-based compensation expense and equity market values. The Accounting Review 79, 251-275.

[4] Ahmed, A.S., E. Kilic, and G. Lobo, 2006. Does recognition versus disclosure matter? Evidence from value-relevance of banks' recognized and disclosed derivative financial instruments. The Accounting Review 81 (3): 567-588.

[5] Ahmed, A.S., E. Kilic, and G. Lobo, 2011. Effect of SFAS 133 on the risk relevance of accounting measures of banks' derivative exposures. The Accounting Review 86, 769-804.

[6] Altamuro, J., R. Johnston, S. Pandit, and H. Zhang, 2011. Operating leases and credit assessments. Working paper. Available at SSRN: http://ssrn.com/abstract=1115924.

[7] Amir, E., 1993, The market valuation of accounting information: the case of postretirement benefits other than pensions. The Accounting Review 68, 703-724.

[8] Anderson, R.W., and S. M. Sundaresan, 1996. The design and valuation of debt contracts. Review of Financial Studies 9: 37-68.

[9] Andrew, M. 1988. Executory Contracts in Bankruptcy: Understanding "Rejection." University of Colorado Law Review 59: 845-932.

[10] Andrew, M. 1991. Executory contracts revisited: A reply to Professor Westbrook. University of Colorado Law Review 62: 1-36.

[11] Asquith, P., A. L. Beatty, and J. P. Weber, 2005. Performance pricing in bank debt contracts. Journal of Accounting and Economics 40, 101-128. 
[12] Ayer, J. D., M. Bernstein, M., and J. Friedland. 2004a. Executory Contracts under $\S 365$. American Bankruptcy Institute Journal 23 (9), 16.

[13] Ayer, J. D., M. Bernstein, M., and J. Friedland. 2004b. Bankruptcy issues for landlords and tenants. American Bankruptcy Institute Journal 23 (8), 54-55.

[14] Ayer, J. D., M. Bernstein, M., and J. Friedland. 2003. The life cycle of a chapter 11 debtor through the debtor's eyes: Part II. American Bankruptcy Institute Journal 22 (8), 32-33, 44-45.

[15] Ayer, J. D., M. Bernstein, M., and J. Friedland. 2004c. "Confirming a Plan." American Bankruptcy Institute Journal 23(10): 16-52.

[16] Ayer, J. D., M. Bernstein, M., and J. Friedland. 2005. "Out-of-court Workouts, Prepacks and Pre-arranged Cases: A Primer." American Bankruptcy Institute Journal 24(3): 16-56.

[17] Barth, M.E., 2006, Research, standard setting, and global financial reporting. Foundations and Trends in Accounting 1, 71-165.

[18] Barth, M.E., W.H. Beaver, and W. R. Landsman, 1996. Value-relevance of banks' fair value disclosures under SFAS 107. The Accounting Review 71, 513-537.

[19] Barth, M. E., W.H. Beaver, and W.R. Landsman, 2001. The relevance of the value relevance literature for financial accounting standards setting: another view. Journal of Accounting and Economics 31: 77-104.

[20] Barth, M.E., G. Ormazabal, and D. J. Taylor, 2012. Asset securitizations and credit risk. The Accounting Review 87, 423-448.

[21] Batta, G., A. Ganguly, and J. Rosett, 2010. Financial statement recasting and credit risk assessment. Working paper. Available at SSRN: http://ssrn.com/abstract=1333902.

[22] Beatty, A., K. Ramesh, and J. Weber, 2002. The importance of accounting changes in debt contracts: The cost of flexibility in covenant calculations. Journal of Accounting and Economics 33: $205-227$.

[23] Bharath, S.T., J. Sunder, S. V. Sunder, 2008. Accounting quality and debt contracting. The Accounting Review 83, 1-28. 
[24] Blanco, R., S. Brennan, and I.W. Marsh, 2005. An empirical analysis of the dynamic relationship between investment-grade bonds and credit default swaps. Journal of Finance 60: $2255-81$.

[25] Bratten, B., P. Choudhary, and K. Schipper, 2012. Evidence that Market Participants Assess Items Similarly when Reliability is not an Issue. The Accounting Review, forthcoming

[26] Bris, A., I. Welch, and N. Zhu, 2006. The costs of bankruptcy: Chapter 7 liquidation versus Chapter 11 Reorganization. Journal of Finance 61, 1253-1303.

[27] CFA Institute. 2007. A Comprehensive Business Reporting Model: Financial Reporting for Investors. CFA Institute Centre for Financial Market Integrity. Available at: http://www.cfainstitute.org/ethics/topics/Pages/comprehensive_business_reporting_model.aspx.

[28] CFA Institute. 2010. Comment Letter on Leases (n. 780). Available at: http://www.cfainstitute.org/ethics/topics/Pages/comprehensive_business_reporting_model.aspx.

[29] Campbell, J. Y., and G. B. Taksler, 2003. Equity volatility and corporate bond yields. Journal of Finance 58 (6): 2321-2350.

[30] Cremers, K. J. M., V. B. Nair, and C. Wei, 2007. Governance mechanisms and bond prices. Review of Financial Studies 20, 1359-1388.

[31] Davydenko, S. A., and I. A. Strebulaev, 2007. Strategic actions and credit spreads: An empirical investigation. Journal of Finance 62(6): 2633-2671.

[32] Dhaliwal, D., H. S. Lee, and M. Neamtiu, 2011. The impact of operating leases on firm financial and operating risk. Journal of Accounting, Auditing, and Finance 26, 151-197.

[33] Duffie, D., 1999. Credit swap valuation. Financial Analysts Journal 55(1): 73-87.

[34] Duffie, D., and D. Lando, 2001. Term structures of credit spreads with incomplete accounting information. Econometrica 69(3): 633-664.

[35] Eberhart, A., W. Moore, and R. Roenfeld, 1990. Security pricing and deviations from the Absolute Priority Rule in bankruptcy proceedings. Journal of Finance 45, 1457-1469. 
[36] Ely, K. M., 1995. Operating lease accounting and the market's assessment of equity risk. Journal of Accounting Research 33 (2): 397-415.

[37] Ernst and Young, 2010. Invitation to Comment - Exposure Draft Leases. Open letter to the IASB and FASB boards. Available at Ernst and Young website.

[38] Fan, H., and S.M. Sundaresan, 2000. Debt valuation, renegotiation, and optimal dividend policy. Review of Financial Studies 13: 1057-1099.

[39] FASB (Financial Accounting Standards Board). 2010. Leases (Topic 840). Exposure Draft. Proposed Accounting Standards Update. Norwalk, CT.

[40] FASB (Financial Accounting Standards Board). 2013a. Exposure Draft. Leases (Topic 842), a revision of the 2010 proposed FASB Accounting Standards Update, Leases (Topic 840). Norwalk, CT.

[41] FASB (Financial Accounting Standards Board). 2013b. Summary of the Feedback on the 2013 ED, Staff Paper, prepared by the staff of the IFRS Foundation and the FASB for discussion at a public meeting of the FASB or IASB. Published 27 September 2013. Retrieved from www.fasb.org.

[42] Francis, Jennifer, D. Nanda, and P. Olsson, 2008. Voluntary disclosure, information quality, and costs of capital. Journal of Accounting Research 46, 53:99.

[43] Fried, J. M. 1996. Executory contracts and performance decisions in bankruptcy. Duke Law Journal 46(3), 517-574.

[44] Gow, I.D., G. Ormazabal, and D. J. Taylor, 2010. Correcting for cross-sectional and time-series dependence in accounting research. The Accounting Review 85, 483-512.

[45] Hahn, D., 2011. The Internal Logic of Assumption of Executory Contracts. University of Pennsylvania Journal of Business Law 13(3): 723-750.

[46] Holthausen, R.W., and R. L. Watts, 2001. The relevance of the value-relevance literature for financial accounting standard setting. Journal of Accounting and Economics 31: 3-75. 
[47] Hull, J. C., M. Predescu, and A. White, 2004. The relationship between credit default swap spreads, bond yields, and credit rating announcements. Journal of Banking and Finance 28: 2789-2811.

[48] Imhoff, E. A., R.C. Lipe, and D.W. Wright, 1991. Operating leases: Impact of constructive capitalization. Accounting Horizons 5 (1): 51-63.

[49] Imhoff, E. A., R.C. Lipe, and D.W. Wright, 1997. Operating leases: Income effects of constructive capitalization. Accounting Horizons 11 (2): 12-32.

[50] Jiang, J.X., 2008. Beating earnings benchmarks and the cost of debt. The Accounting Review $83,377-416$.

[51] Jorion, P. and G. Zhang, 2009. Credit contagion from counterparty risk. Journal of Finance 64: 2053-2087.

[52] Kim, S., P. Kraft, and S.G. Ryan, 2013. Financial statement comparability and credit risk. Review of Accounting Studies 18, 783-823.

[53] Kraft, P. 2011. Rating agency adjustments to GAAP financial statements and their effect on ratings and bond yields. Working paper.

[54] Lim, S. C., S. Mann, and V. Mihov, 2005. Market evaluation of off-balance sheet financing: You can run but you can't hide. Working paper.

[55] Lee, K.J. 2010. Purchase obligations, earnings persistence and stock returns. Working paper.

[56] Longstaff, F. A., S. Mithal, and E. Neis, 2005. Corporate yield spreads: Default risk or liquidity? New evidence from the credit default swap market. Journal of Finance 60 (5): 2213-2253.

[57] Maizel S. R. 2002. What's new and different about executory contracts and unexpired leases in bankruptcy proceedings. Prepared for the Meeting of the Business Bankruptcy Committee, American Bar Association. Retrieved from: http://apps.americanbar.org/buslaw/newsletter/0002/materials/bankruptcy.pdf.

[58] Mansi, S. A., W. F. Maxwell, and D. P. Miller, 2004. Does auditor quality and tenure matter to investors? Evidence from the bond market. Journal of Accounting Research 42, 755-793. 
[59] Mella-Barral, P., and W. R. Perraudin, 1997. Strategic debt service. Journal of Finance 52 (2): 531-556.

[60] Merton, R. C., 1974. On the pricing of corporate debt: The risk structure of interest rates. Journal of Finance 29, 449-470.

[61] Palank, J. 2012. "Reddy Ice Files for Bankruptcy Protection" Wall Street Journal. April 12, 2012.

[62] Petersen, M. A. 2009. Estimating standard errors in finance panel data sets: Comparing approaches. Review of Financial Studies 22: 435-480.

[63] Pittman, J. A., and S. Fortin,. 2004. Auditor choice the cost of debt capital for newly public firms. Journal of Accounting and Economics 37, 113-136.

[64] Revsine, L., D.W. Collins, W. B. Johnson, and H.F. Mittelstaedt, 2009. Financial Reporting and Analysis (4th ed.). McGraw-Hill Irwin.

[65] Robinson, T. R., H. van Greuning, E. Henry, and M.A. Broihahn, 2009. International Financial Statement Analysis (CFA Institute Investment Series). John Wiley \& Sons Inc, Hoboken NJ.

[66] Russell, R., 2011. Dealing with companies in financial distress. Texas Lawyer's Bankruptcy Law e-Newsletter, February 1.

[67] Securities and Exchange Commission (SEC). 2003. Disclosure in Management's Discussion and Analysis about Off-Balance Sheet Arrangements and Aggregate Contractual Obligations. Final rule, Release Nos. 33-8182; 34-47264; FR-67, issued January 27, 2003, available at http://www.sec.gov/rules/final/33-8182.htm.

[68] Securities and Exchange Commission (SEC). 2005. Report and Recommendations Pursuant to Section 401(c) of the Sarbanes-Oxley Act of 2002 On Arrangements with Off-Balance Sheet Implications, Special Purpose Entities, and Transparency of Filings by Issuers. Issued June 15, 2005. Available at Ersnt and Youn: http://www.sec.gov/news/studies/soxoffbalancerpt.pdf.

[69] Sengupta, P. and Z. Wang, 2011. Pricing of off-balance sheet debt: how do bond market participants use the footnote disclosures on operating leases and postretirement benefit plans? Accounting 85 Finance 51 (3): 787-808. 
[70] Standard \& Poor's, 2008. Corporate Ratings Criteria. Available at: www.corporatecriteria.standardandpoors.com.

[71] _-__-______, 2002. CreditStats Operating Lease Analytical Model, New York: Standard and Poor's.

[72] Stickney, C. P., P.R. Brown, and J.M. Wahlen, 2007. Financial Reporting, Financial Statement Analysis, and Valuation: A Strategic Perspective (6th ed.) Thomson South-Western.

[73] Triantis, G. G., 1993. The Effects of Insolvency and Bankruptcy on Contract Performance and Adjustment. University of Toronto Law Journal 43, 679-710.

[74] Venkatachalam, M. , 1996. Value-relevance of derivatives disclosures. Journal of Accounting and Economics 22, 327-355.

[75] Warren, E., and J. L. Westbrook. 2005. "Contracting out of Bankruptcy: An Empirical Intervention." Harvard Law Review 118(4): 1197-1254.

[76] White, G. I., A.C. Sondhi, and D. Fried, 1998. The Analysis and Use of Financial Statements (2nd ed.). John Wiley \& Sons Inc. 
Table 1

\section{List of Variables}

$\log ($ Spread) = natural log of the firm's 5-year (Credit Default Swap) CDS spread in basis points.

Data source: Markit.

Asset $\quad=$ annualized volatility of the firm's assets measured over the prior six months, calculated

Volatility from daily asset value data.

Data source: Moody's KMV.

B/S Debt = Debt $\div$ (MV of Equity + Debt + PV Leases + PV Purchase Obligations $),$ where

- $\quad$ Debt $=$ Short-term Debt + Long-term Debt + Preferred Stock

- $\quad$ MV of Equity = Market Value of Equity (Share price $\times$ shares outstanding)

- $\quad$ PV Leases $=$ Present Value of Minimum Rental Commitments discounted at the risk free rate

- $\quad$ PV Purchase Obligations $=$ Present Value of Purchase Obligations as disclosed in FR-67 table, discounted at the risk free rate

Data source: Compustat, CRSP, Datastream (5-year swap rate).

For leases, authors' hand-collected data missing Compustat data from firms' Form 10-K.

For purchase obligations, authors' hand-collected data from firms' Form 10-K.

Op. Leases $\quad$ = PV Leases $\div$ (MV of Equity+ Debt + PV Leases +PV Purchase Obligations).

Purchase $\quad=$ PV Purchase Obligations $\div$ (MV of Equity + Debt + PV Leases +PV Purchase Obligations).

Obligations

Assets $\quad=$ total book assets.

(\$ millions) Data source: Compustat.

Non-fixed = one minus the ratio of net property, plant and equipment to total assets.

Assets Data source: Compustat.

Short-term = ratio of debt in current liabilities to total debt and preferred stock $=$ ST Debt $/$ Debt

Debt Ratio Data source: Compustat.

Inst. $\quad=$ percentage of total equity owned by institutional shareholders.

Ownership Data source: Thompson Financial Ownership Database and CRSP.

No. Inst. $\quad=$ the normalized number of institutional holders, calculated as the log of the number of

Shareholders institutional investors divided by the log of the market value of equity.

Data source: Thompson Financial Ownership Database and CRSP.

CEO = percentage of total equity owned by the Chief Executive Officer of the firm.

Shareholding Data source: Execucomp and CRSP.

Essential/ = dummy variables. Essential is equal to 1 if purchase-obligations appear to be essential for

Non-Essential the functioning of a bankrupt firm as a going concern. Non-Essential is equal to 1 if purchase obligations appear not to be essential.

Data source: 10-k, firm websites. 
Table 2

Summary Statistics and Correlation Matrix

Panel A presents descriptive statistics for CDS spreads, volatility, and leverage measures for 2846 firm-quarters (372 firms). Data are at the end of each quarter from 2004Q1 to 2006Q1. Panel B presents the correlation matrix. Variable are defined in Table 1.

Panel A: Descriptive Statistics

\begin{tabular}{|c|c|c|c|c|c|c|c|c|c|c|}
\hline & $\begin{array}{c}\log \\
\text { (Spread) }\end{array}$ & $\begin{array}{c}\text { Asset } \\
\text { Volatility } \\
\end{array}$ & $\begin{array}{l}\text { Assets (\$ } \\
\text { millions) }\end{array}$ & B/S Debt & $\begin{array}{c}\text { Op. } \\
\text { Leases }\end{array}$ & $\begin{array}{c}\text { Purchase } \\
\text { Obligations }\end{array}$ & $\begin{array}{c}\text { Non-fixed } \\
\text { Assets }\end{array}$ & $\begin{array}{c}\text { Short- } \\
\text { term Debt } \\
\text { Ratio }\end{array}$ & $\begin{array}{c}\text { Institutional } \\
\text { Ownership }\end{array}$ & $\begin{array}{l}\text { Number inst. } \\
\text { Shareholders }\end{array}$ \\
\hline mean & 3.71 & 0.130 & 21713 & 0.190 & 0.038 & 0.060 & 0.668 & 0.149 & 0.747 & 0.305 \\
\hline sd & 0.77 & 0.044 & 54889 & 0.135 & 0.051 & 0.088 & 0.224 & 0.175 & 0.172 & 0.023 \\
\hline $\mathrm{p} 25$ & 3.20 & 0.100 & 3864 & 0.095 & 0.010 & 0.007 & 0.512 & 0.016 & 0.652 & 0.295 \\
\hline p50 & 3.66 & 0.122 & 8557 & 0.158 & 0.019 & 0.029 & 0.727 & 0.092 & 0.772 & 0.307 \\
\hline $\mathrm{p} 75$ & 4.14 & 0.152 & 20037 & 0.256 & 0.040 & 0.075 & 0.846 & 0.222 & 0.858 & 0.318 \\
\hline $\mathrm{N}$ & 2846 & 2846 & 2846 & 2846 & 2846 & 2846 & 2846 & 2846 & 2846 & 2846 \\
\hline
\end{tabular}

Panel B: Correlation Matrix

\begin{tabular}{|c|c|c|c|c|c|c|c|c|c|}
\hline & $\begin{array}{c}\text { Log } \\
\text { (Spread) }\end{array}$ & $\begin{array}{c}\text { Asset } \\
\text { Volatility }\end{array}$ & $\begin{array}{l}\text { Assets (\$ } \\
\text { millions) }\end{array}$ & B/S Debt & $\begin{array}{c}\text { Op. } \\
\text { Leases }\end{array}$ & $\begin{array}{c}\text { Purchase } \\
\text { Obligations }\end{array}$ & $\begin{array}{c}\text { Non-fixed } \\
\text { Assets }\end{array}$ & $\begin{array}{c}\text { Short- } \\
\text { term Debt } \\
\text { Ratio } \\
\end{array}$ & $\begin{array}{c}\text { Institutional } \\
\text { Ownership }\end{array}$ \\
\hline$\overline{\log (\text { Spread) }}$ & 1 & & & & & & & & \\
\hline Asset Volatility & -0.09 & 1 & & & & & & & \\
\hline Assets ( $\$$ millions) & -0.05 & -0.22 & 1 & & & & & & \\
\hline B/S Debt & 0.55 & -0.48 & 0.27 & 1 & & & & & \\
\hline Op. Leases & 0.24 & -0.07 & -0.09 & 0.01 & 1 & & & & \\
\hline Purchase Obligations & 0.07 & -0.12 & 0.03 & 0.00 & -0.01 & 1 & & & \\
\hline Non-fixed Assets & -0.04 & -0.15 & 0.07 & -0.12 & -0.11 & -0.12 & 1 & & \\
\hline Short-term Debt Ratio & -0.26 & -0.04 & 0.16 & -0.13 & -0.12 & -0.05 & 0.27 & 1 & \\
\hline Institutional Ownership & 0.25 & 0.08 & -0.20 & 0.00 & 0.20 & -0.05 & 0.14 & -0.09 & 1 \\
\hline Number inst. Shareholders & -0.44 & -0.06 & 0.16 & -0.35 & -0.11 & -0.08 & 0.25 & 0.22 & 0.24 \\
\hline
\end{tabular}


Table 3

\section{Regression of Log CDS Spreads}

Panel A presents results of regressing Log CDS spreads on explanatory variables. The sample has 2,846 firm-quarters (372 firms). Data are at the end of each quarter from 2004Q1 to 2006Q1. Standard errors are robust to heteroskedasticity and clustered by firm. Panel B presents tests of equivalence of the coefficients on B/S Debt, Op. Leases and Purchase Obligations. Variables are defined in Table 1.

Panel A: Regression results

\begin{tabular}{|c|c|c|c|}
\hline $\log ($ Spread) & $(1)$ & (2) & (3) \\
\hline \multirow[t]{2}{*}{ B/S Debt } & $3.63^{* * *}$ & $3.93^{* * *}$ & $3.25^{* * *}$ \\
\hline & (14.69) & $(14.64)$ & (9.35) \\
\hline \multirow[t]{2}{*}{ Op. Leases } & & $3.46^{* * *}$ & $2.68^{* * * *}$ \\
\hline & & $(6.05)$ & (5.15) \\
\hline \multirow[t]{2}{*}{ Purchase Obligations } & & $1.04^{* * *}$ & $0.90^{* * * *}$ \\
\hline & & (3.43) & $(3.00)$ \\
\hline \multirow[t]{2}{*}{ Asset Volatility } & $3.45^{* * *}$ & $3.62^{* * *}$ & $2.81^{* * * *}$ \\
\hline & (5.66) & $(6.22)$ & (4.15) \\
\hline \multirow[t]{2}{*}{ Log of Assets } & $-0.20^{* * *}$ & $-0.19^{* * *}$ & $-0.09^{* * *}$ \\
\hline & $(-7.79)$ & $(-7.54)$ & $(-2.86)$ \\
\hline \multirow[t]{2}{*}{ Non-fixed Assets } & & & $0.45^{* * * *}$ \\
\hline & & & (3.97) \\
\hline \multirow[t]{2}{*}{ Short-term Debt Ratio } & & & $-0.43^{* * *}$ \\
\hline & & & $(-4.59)$ \\
\hline \multirow[t]{2}{*}{ Inst. Ownership } & & & $0.89^{* * *}$ \\
\hline & & & (3.60) \\
\hline \multirow[t]{2}{*}{ No. Inst. Shareholders } & & & $-7.55^{* * *}$ \\
\hline & & & $(-3.16)$ \\
\hline Quarter-Effects & yes & yes & yes \\
\hline$N$ & 2846 & 2846 & 2846 \\
\hline Adj. $R^{2}$ & 0.474 & 0.502 & 0.561 \\
\hline
\end{tabular}

Panel B: Tests

Tests of equivalence of coefficients of B/S Debt, Op. Leases and Purchase Obligations

Op. Leases - B/S Debt

$-0.47 \quad-0.57$
$-(-0.75)$

$(-0.75) \quad(-1.03)$

Purchase Obligations - B/S Debt

$-2.89^{* * *}-2.35^{* * *}$

$(-7.62) \quad(-5.87)$

Op. Leases - Purchase Obligations

$2.42^{* * *} \quad 1.78^{* * * *}$

(3.76) (3.11) 


\section{Table 4.}

\section{Regression of Log CDS: Robustness checks}

Table presents results of regressing Log CDS spreads on explanatory variables. Except where noted, the sample has 2,846 firm-quarters (372 firms). Data are at the end of each quarter from 2004Q1 to 2006Q1. Standard errors are robust to heteroskedasticity and clustered by firm. Variables are defined in Table 1.

\begin{tabular}{|c|c|c|c|c|c|c|c|c|c|c|}
\hline $\log ($ Spread $)$ & $\begin{array}{c}(1) \\
\text { Balanced } \\
\text { panel only }\end{array}$ & $\begin{array}{c}\text { (2) } \\
\text { Inv. Grade } \\
\text { only }\end{array}$ & $\begin{array}{c}\text { (3) } \\
\begin{array}{c}\text { Sp. Grade } \\
\text { only }\end{array}\end{array}$ & $\begin{array}{c}(4) \\
\mathrm{PV} \text { at } \\
k_{d}\end{array}$ & $\begin{array}{c}(5) \\
\text { Equity } \\
\text { volatility }\end{array}$ & $\begin{array}{c}(6) \\
\text { CEO } \\
\text { sharehold. }\end{array}$ & $\begin{array}{c}\text { (7) } \\
\text { EBIT and } \\
\text { Int. Cov. }\end{array}$ & $\begin{array}{c}\text { (8) } \\
\text { Industry } \\
\text { effects }\end{array}$ & $\begin{array}{c}(9) \\
\text { Median } \\
\text { regression }\end{array}$ & $\begin{array}{c}\text { (10) } \\
\text { Double- } \\
\text { clustering }\end{array}$ \\
\hline B/S Debt & $\begin{array}{l}3.28^{\text {**** }} \\
(8.41)\end{array}$ & $\begin{array}{l}2.49^{\text {**** }} \\
(8.16)\end{array}$ & $\begin{array}{l}3.02^{* * * *} \\
(4.47)\end{array}$ & $\begin{array}{l}3.25^{* * * *} \\
(9.37)\end{array}$ & $\begin{array}{l}2.71^{\text {**** }} \\
(10.81)^{2}\end{array}$ & $\begin{array}{l}3.24^{\text {*** }} \\
(9.16)\end{array}$ & $\begin{array}{l}3.00 \\
(8.17)\end{array}$ & $\begin{array}{l}3.23^{\text {**** }} \\
(9.97)\end{array}$ & $\begin{array}{l}3.27^{* * * *} \\
(8.06)\end{array}$ & $\begin{array}{l}3.25^{\text {**** }} \\
(9.93)\end{array}$ \\
\hline Op. Leases & $\begin{array}{l}3.00^{\text {**** }} \\
(4.21)\end{array}$ & $\begin{array}{l}2.19^{* * *} \\
(5.30)\end{array}$ & $\begin{array}{l}2.76^{* * * *} \\
(2.85)\end{array}$ & $\begin{array}{l}2.59^{\text {**** }} \\
(4.94)\end{array}$ & $\begin{array}{l}2.500^{* * * *} \\
(5.24)\end{array}$ & $\begin{array}{l}2.64^{* * * *} \\
(4.94)\end{array}$ & $\begin{array}{l}2.67^{\text {**** }} \\
(5.15)\end{array}$ & $\begin{array}{l}2.64^{\text {**** }} \\
(4.34)\end{array}$ & $\begin{array}{l}2.32^{* * * *} \\
(4.25)\end{array}$ & $\begin{array}{l}2.68^{* * * *} \\
(5.58)\end{array}$ \\
\hline Purchase Obligations & $\begin{array}{l}0.96^{* * * *} \\
(2.78)\end{array}$ & $\begin{array}{l}0.76^{* * * *} \\
(3.48)\end{array}$ & $\begin{array}{l}1.67^{* *} \\
(2.10)\end{array}$ & $\begin{array}{l}0.87^{\text {**** }} \\
(2.96)\end{array}$ & $\begin{array}{l}0.53^{* *} \\
(2.44)\end{array}$ & $\begin{array}{l}0.70 \text { ** } \\
(2.17)\end{array}$ & $\begin{array}{l}0.80^{\text {**** }} \\
(2.75)\end{array}$ & $\begin{array}{l}1.09^{\text {**** }} \\
(4.10)\end{array}$ & $\begin{array}{l}0.89^{* * *} \\
(3.58)\end{array}$ & $\begin{array}{l}0.90^{* * * *} \\
(3.19)\end{array}$ \\
\hline Asset Volatility & $\begin{array}{l}2.86^{* * *} \\
(3.57)\end{array}$ & $\begin{array}{l}2.82^{* * * *} \\
(4.55)\end{array}$ & $\begin{array}{l}3.89^{* *} \\
(2.04)\end{array}$ & $\begin{array}{l}2.80^{* * * *} \\
(4.12)\end{array}$ & & $\begin{array}{l}3.03^{\text {**** }} \\
(4.38)\end{array}$ & $\begin{array}{l}2.63^{* * * *} \\
(3.98)\end{array}$ & $\begin{array}{l}2.56^{* * * *} \\
(3.94)\end{array}$ & $\begin{array}{l}2.68^{* * * *} \\
(4.07)\end{array}$ & $\begin{array}{l}2.81^{* * * *} \\
(4.00)\end{array}$ \\
\hline Log of Assets & $\begin{array}{l}-0.07^{* *} \\
(-2.04)\end{array}$ & $\begin{array}{l}-0.11^{\text {**** }} \\
(-3.68)\end{array}$ & $\begin{array}{r}0.04 \\
(0.46)\end{array}$ & $\begin{array}{l}-0.09^{* * * *} \\
(-2.86)\end{array}$ & $\begin{array}{l}-0.08^{* * * *} \\
(-2.96)\end{array}$ & $\begin{array}{l}-0.06^{\text {** }} \\
(-2.03)\end{array}$ & $\begin{array}{l}-0.09^{\text {***** }} \\
(-2.92)\end{array}$ & $\begin{array}{l}-0.11^{\text {**** }} \\
(-3.42)\end{array}$ & $\begin{array}{l}-0.11^{* * * *} \\
(3.72)\end{array}$ & $\begin{array}{l}-0.09^{* * * *} \\
(-2.68)\end{array}$ \\
\hline Non-fixed Assets & $\begin{array}{l}0.51^{\text {*水 }} \\
(3.98)\end{array}$ & $\begin{array}{l}0.33^{\text {**** }} \\
(3.15)\end{array}$ & $\begin{array}{r}0.39 \\
(1.47)\end{array}$ & $\begin{array}{l}0.45^{* * * *} \\
(3.92)\end{array}$ & $\begin{array}{l}0.39^{* * * *} \\
(3.94)\end{array}$ & $\begin{array}{l}0.47^{\text {**** }} \\
(4.10)\end{array}$ & $\begin{array}{l}0.43^{\text {*** }} \\
(3.71)\end{array}$ & $\begin{array}{l}0.37^{\text {**** }} \\
(2.74)\end{array}$ & $\begin{array}{l}0.40^{* * * *} \\
(3.24)\end{array}$ & $\begin{array}{l}0.45^{\text {**** }} \\
(4.14)\end{array}$ \\
\hline Short-term Debt Ratio & $\begin{array}{l}-0.48^{\text {**** }} \\
(-3.98)\end{array}$ & $\begin{array}{l}-0.44^{* * *} \\
(-5.15)\end{array}$ & $\begin{array}{l}-0.49 \\
(-1.58)\end{array}$ & $\begin{array}{l}-0.44^{* * *} \\
(-4.61)\end{array}$ & $\begin{array}{l}-0.44^{* * *} \\
(-4.71)\end{array}$ & $\begin{array}{l}-0.45^{\text {**** }} \\
(-4.69)\end{array}$ & $\begin{array}{l}-0.39^{* * * *} \\
(-4.18)\end{array}$ & $\begin{array}{l}-0.40^{\text {*** }} \\
(-4.41)\end{array}$ & $\begin{array}{l}-0.42^{* * *} \\
(-4.26)\end{array}$ & $\begin{array}{l}-0.43^{* * *} \\
(-4.72)\end{array}$ \\
\hline Inst. Ownership & $\begin{array}{l}0.93^{\text {*** }} \\
(3.18)\end{array}$ & $\begin{array}{l}0.51^{\text {** }} \\
(2.34)\end{array}$ & $\begin{array}{l}1.05^{* * *} \\
(2.88)\end{array}$ & $\begin{array}{l}0.91^{* * *} \\
(3.64)\end{array}$ & $\begin{array}{l}0.65^{* * *} \\
(2.92)\end{array}$ & $\begin{array}{l}1.09^{* * * *} \\
(4.52)\end{array}$ & $\begin{array}{l}0.87^{\text {**** }} \\
(3.64)\end{array}$ & $\begin{array}{l}0.85^{\text {*** }} \\
(3.43)\end{array}$ & $\begin{array}{l}0.82^{* * * *} \\
(3.76)\end{array}$ & $\begin{array}{l}0.89^{\text {**** }} \\
(3.50)\end{array}$ \\
\hline No. Inst. Shareholders & $\begin{array}{l}-6.83^{* * * *} \\
(-2.72)\end{array}$ & $\begin{array}{l}-4.62^{* *} \\
(-2.30)\end{array}$ & $\begin{array}{l}-6.63 \\
(-1.32)\end{array}$ & $\begin{array}{l}-7.59^{\text {*** }} \\
(-3.16)\end{array}$ & $\begin{array}{l}-5.89^{* * * *} \\
(-2.77)\end{array}$ & $\begin{array}{l}-8.90^{* * *} \\
(-3.57)\end{array}$ & $\begin{array}{l}-7.07^{* * * *} \\
(-3.07)\end{array}$ & $\begin{array}{l}-6.87^{\text {***⿰冫⿰亅⿱丿丶丶 }} \\
(-2.95)\end{array}$ & $\begin{array}{l}-7.72^{* * * *} \\
(-3.31)\end{array}$ & $\begin{array}{l}-7.55^{\text {**** }} \\
(-3.25)\end{array}$ \\
\hline Equity volatility & & & & & $\begin{array}{l}3.10^{* * * *} \\
(9.09)\end{array}$ & & & & & \\
\hline CEO Shareholding & & & & & & $\begin{array}{r}1.13 \\
(1.56)\end{array}$ & & & & \\
\hline EBIT over Assets & & & & & & & $\begin{array}{l}-0.91 \\
(1.84)\end{array}$ & & & \\
\hline Interest rate coverage & & & & & & & $\begin{array}{l}-0.05 \\
(0.56)\end{array}$ & & & \\
\hline Industry-Effects & & & & & & & & yes & & \\
\hline Quarter-Effects & yes & yes & yes & yes & yes & yes & yes & yes & yes & yes \\
\hline$N$ & 2223 & 2305 & 541 & 2846 & 2846 & 2632 & 2811 & 2846 & 2846 & 2846 \\
\hline Adj. $R^{2}$ or Pseudo- $R^{2}$ & 0.580 & 0.473 & 0.497 & 0.560 & 0.613 & 0.575 & 0.561 & 0.580 & 0.347 & 0.561 \\
\hline
\end{tabular}

$* * * p<0.01, * * p<0.05, * p<0.1$ (two-tailed) 
Table 5

Regression of Log CDS Spreads: Interactions with Purchase-Obligation Essentiality

Panel A presents results of regressing Log CDS spreads on explanatory variables. The sample has 2,846 firm-quarters (372 firms). Data are at the end of each quarter from 2004Q1 to 2006Q1. Standard errors are robust to heteroskedasticity and clustered by firm. Panel B presents tests of equivalence of coefficients when essentiality is high or low. Variables are defined in Table 1.

\section{Panel A: Regression results}

\begin{tabular}{lcc}
\hline Log( Spread) & $(1)$ & $(2)$ \\
\hline B/S Debt & $3.94^{* * *}$ & $3.11^{* * *}$ \\
& $(15.01)^{* * *}$ & $(8.98)$ \\
Op. Leases & $3.35^{* * *}$ & $2.58^{* * *}$ \\
& $(6.06)^{* * *}$ & $(5.21)$ \\
Purchase Obligations & $1.08^{* * *}$ & $0.61^{*}$ \\
& $(3.40)$ & $(1.86)$ \\
Purchase Obligations $\times$ Non- Essential & $-1.09^{* *}$ & -0.56 \\
& $(-2.35)$ & $(-1.25)$ \\
Purchase Obligations $\times$ Essential & $1.55^{* * *}$ & $1.89^{* * *}$ \\
& $(2.23)$ & $(2.91)$ \\
Asset Volatility & $3.57^{* * *}$ & $2.66^{* * *}$ \\
& $(6.20)$ & $(4.18)$ \\
Log of Assets & $-0.19^{* * *}$ & $-0.10^{* * *}$ \\
& $(-7.63)$ & $(-3.31)$ \\
Non-fixed Assets & & $0.47^{* *}$ \\
& & $(4.26)$ \\
Short-term Debt Ratio & & $-0.44^{* *}$ \\
Inst. Ownership & & $(-4.75)$ \\
No. Inst. Shareholders & & $0.83^{* * *}$ \\
Quarter-Effects & & $(3.55)$ \\
\hline & & $-6.76^{* * *}$ or Pseudo- ${ }^{2}$ \\
& & $(-2.99)$ \\
& & yes \\
\hline
\end{tabular}

Panel B: Tests

Tests of Purchase Obligations interacted with Essentiality

Purchase Obligations + Purchase Obligations $\times$ Non-Essential

$-0.02 \quad 0.05$

Op. Leases $-($ Purchase Obligations + Purchase Obligations $\times$ Essential)

$\begin{array}{rr}0.73 & 0.10 \\ (0.82) & (0.13)\end{array}$

$* * * p<0.01, * * p<0.05, * p<0.1$ (two-tailed) 